d. $C$

NoV 291993

OSTI

Multisphere Neutron

Spectroscopy Measurements at the

Los Alamos National Laboratory

Plutonium Facility 
An Affirmatiz' Action/Equal Opportunity Employer

This report wers prepared as an account of anork sponsored by an arency of the

United States Covernme'nt. Neither The Regents of the Untersity of Califormia, the

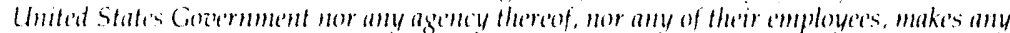

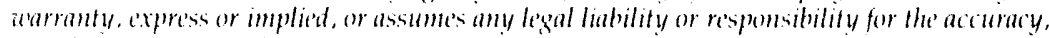
completeness, or usefulness of any information, apparatus, product, or process disclosed, or represents that its use would not infringe priontely oundel rights. Reference herein to any specific

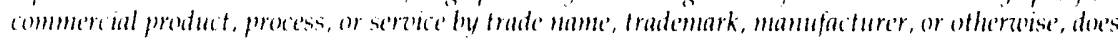

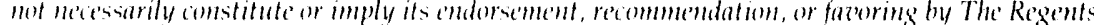

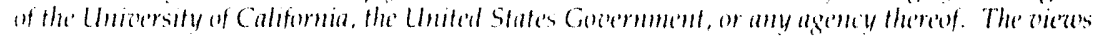

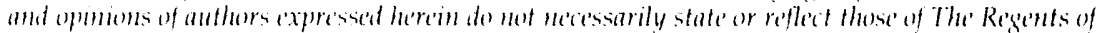

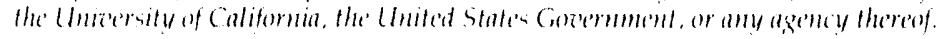




\section{Multisphere Neutron}

Spectroscopy Measurements at the

Los Alamos National Laboratory

Plutonium Facility

W. F. Harvey and F. Hajnal* 


\title{
MULTISPHERE NEUTRON SPECTROSCOPY MEASUREMENTS AT THE LOS ALAWOS NATIONAL LABORATORY PLUTONIUM FACILITY
}

\author{
by
}

\author{
W. F. Harvey and F. Hajnal
}

\begin{abstract}
Multisphere neutron spectroscopy methods are applied to measure representative working fields within the Los Alamos National Laboratory (LANL) Plutonium Facility. This facility hosts dynamic processes, which include the fabrication of ${ }^{238} \mathrm{Pu}$ heat sources for radioisotope generators used to power space equipment and a variety of plutonium research programs that involve recovery, hydrofluorination, and metal production. Neutron fluence per unit lethargy, as a function of neutron energy measured for locations throughout this facility, are described. Dosimeter/remmeter response functions [e.g., determined for a 22.8-cm-diameter neutron rem detector (NRD), an Andersson/Braun-type neutron "Snoopy" monitor, track-etch CR-39, BDI-100 bubble detectors, and Kodak type A nuclear track emulsion film, (NTA)] are folded into these spectra to calculate absolute response values of counts, tracks, or bubbles per unit-dose equivalent. The relative response values per unit- dose equivalent for bare and albedo ${ }^{6} \mathrm{LiF}$-based thermoluminescent dosimeters (TLDs) are also calculated to estimate response scenarios encountered with use of the LANL-TLD. These results are further compared to more conventional methods of estimating neutron spectral energies such as the "9-to-3 ratio" method.

The conclusions of this study are summarized as follows: (i) the average Plutonium Facility quotient of neutron to gamma- and $\mathrm{x}$-ray-dose equivalent was measured to be 2.5 while photon doseequivalent rates were measured to have a range in hall and storage ar cas of 3.84 to $80.0 \mu \mathrm{Sv} / \mathrm{h}(0.384$ to $8.00 \mathrm{mrem} / \mathrm{h}$ ), respectively; (ii) reference neutron dosimetry methods used for calibration result in an average $20 \%$ overresponse (i.e., values ranging from $6 \%$ to $30 \%$ ) of the Eberline $22.9-\mathrm{cm}$ NRD when used in the Plutonium Facility; (iii) when the response functions of BDI-100, CR-39, and NTA film are folded into the measured Plutonium Facility neutron spectra, these dosimeters are calculated to underrespond (i.e., relative to their measured response values for bare ${ }^{252} \mathrm{Cf}$ ) by values of $9.5 \%, 14 \%$, and 30\%, respectively; (iv) when the relative response values for bare and albedo ${ }^{6} \mathrm{LiF}$ TLDs are folded into the measured Plutonium Facility neutron spectra, the inherent thermal and epithermal sensitivities of these dosimeters result in significant changes in response values representative of highly moderated and dynamic processes; $(v)$ due to the dynamic and significant presence of thermal and epithermal neutrons encountered at specific locations in the Plutonium Facility, applied TLD neutron correction factors are valid primarily for static, site-specific processes; and $(v i)$ properly calibrated BDI-100 and CR-39 dosimeters are calculated to be more accurate than the currently used LANL-TLD system for quantifying neutron-dose equivalents encountered in the Plutonium Facility.

Unless valid and site-specific neutron correction factors are applied to all encountered fields, the currently used LANL TLD-based dosimeter will not measure neutron-dose equivalents to a high degree of accuracy for individuals who oversee many operations and processes within this facility. The inherent nature of properly calibrated bubble and CR-39 dosimeters renders them less sensitive when compared to TLDs in changing thermal/epithermal neutron fields. This fact, combined with calculated spectral response values, demonstrates that both BDI-100 and CR-39 dosimeters are more accurate than the currently used LANL-TLD system in measuring neutron-dose equivalents imparted for dynamic and highly moderated neutron processes encountered in the LANL Plutonium Facility.
\end{abstract}

The health physics impact of implementing ICRP 60 recommendations within the Plutonium Facility is stated in a final section of this report. These recommendations result in calculated radiationinduced stochastic effects that are $2.32 \pm 0.064$-fold greater than are estimated using current Department of Energy (DOE) methods. 


\section{INTRODUCTION}

Dynamic processes within the Los Alamos National Laboratory (LANL) Plutonium Facility result in time-, and spatialvariant neutron spectra. Changing spectral quantities within this facility routinely challenge the concept of accuracy of a given dosimeter measurement. Specifically, for a given process and location, knowledge of neutron fluence rate and spectral energies is required. Only when these physical quantities are measured and compared to calibration neutron spectra using the best technology available can the accuracy of a remmeter/dosimeter system have meaning and, hence, be defined. Evolving neutron source geometries, having variable neutron spectra, combined with changes in hydrogenous shielding and/or material processing necessitate continuous measurements of neutron spectra throughout this facility.

Neutron measurements in the Plutonium Facility are complicated by at least three modifiers. First, this facility contains hydrogenous shielding including reinforced concrete, Lucite, and water, each representing a significant moderating medium for fission-produced neutrons. Hydrogenous shielding material results in neutron energies ranging in excess of ten decades (i.e., from thermal to greater than $20 \mathrm{MeV}$ ) with significant thermal and epithermal components. Second, processes such as hydrofluorination result in time-variant neutron spectral distributions and emission rates. Personnel dose equivalents resulting from neutrons originating from these processes are difficult to quantify because of changes in neutron energies; associated quality factors $(\mathrm{Q})$; and a lack of dynamic neutron correction factors for systems based on thermoluminescent dosimetry (TLD). Third, tradeoffs exist between cnergy resolution of a given measurement technique, detector response flatness, and the dynamic range of neutron energies that can be measured using a single type of detector. This dilemma implies that the more precise the energy resolution is for a detector used to measure a portion of a neutron spectrum, the more types of detectors and unfolding techniques are required to measure the entire range of spectral energies. In areas where multiple measurements are required (e.g., material processing areas within the Plutonium Facility), as-low-as-reasonably achievable (ALARA) concepts, including time, distance, and shielding factors dominate the decision on how to proceed with neutron field characterizations. For these reasons we performed our measurements throughout the Plutonium Facility using methods of multisphere neutron spectroscopy. ${ }^{2 \cdot 7}$ These methods sacrificed spectral energy resolution for the ability to isotropically monitor neutron energies encountered at a significanuly increased number of locations within this facility. These measurements were performed to better understand the response of various remmeters and dosimeters to be used in quantifying dose equivalents imparted in this unique environment; the eventual goal was to upgrade LANL's personnel neutron dosimetry methods.

\section{METHODS}

\section{Multisphere spectrometry}

The multisphere neutron spectroscopy system, response values, and associated clectronics used for our measurements were obtained through a consulting agreement with the United States Department of Energy (DOE) Environmental Measurements Laboratory (EML) in New York ${ }^{6,8-10}$ This system is composed of 12, 5.08-cm-diameter, spherical detectors each pressurized near $5.07^{*} 10^{4} \mathrm{~Pa}(0.507$ standard atmosphere) with an enriched fill gas composed of $95 \%{ }^{10} \mathrm{BF}_{3}$. Ten of these spherical detectors are surrounded by polyethylene formed at a specific gravity of $0.950 \mathrm{~g} / \mathrm{cm}^{3}$. These spheres are covered with hydroformed cadmium cast at a thickness of $0.76 \mathrm{~mm}$. One of the remaining two detectors also contains the cadmium sheet covering its periphery. Each cadmium covering acts to absorb thermal neutrons and reduce the ${ }^{10} \mathrm{BF}_{3}$ inherent overresponse at these energies. The described detector and sphere dimensions are shown in Table 1. The calculated and measured neutron energy response values for each sphere and detector, including a detailed discussion of spectral unfolding methods used with this system, are described elsewhere. ${ }^{6}$ This neutron spectroscopy system has a history of use in excess of 20 years for quality measurements made at many institutions, including universities, the National Aeronautics and Space Administration (NASA), various commercial power reactors, and selected areas within the Department of Defense (DoD)/DOE complex.

Table 1. Description of the EML multisphere system complete with 5.08-cm-diameter ${ }^{10} \mathrm{BF}_{3}$ detectors.

\begin{tabular}{|cccc|}
$\begin{array}{c}\text { Sphere } \\
\text { Number }\end{array}$ & $\begin{array}{c}\text { Polyethylene } \\
\text { Diameter }(\mathrm{cm})\end{array}$ & $\begin{array}{c}\text { Cd-Covered } \\
(\mathrm{y}=\mathrm{yes} ; \mathrm{n}=\mathrm{no})\end{array}$ & Volume $\left(\mathrm{cm}^{3}\right)$ \\
\hline 1 & Detector Only & $n$ & 68.6 \\
2 & Detector Only & $y$ & 68.6 \\
3 & 7.62 & $y$ & 232 \\
4 & 7.85 & $y$ & 253 \\
5 & 10.0 & $y$ & 525 \\
6 & 10.2 & $y$ & 562 \\
7 & 12.8 & $y$ & 1085 \\
8 & 14.9 & $y$ & 1744 \\
9 & 15.2 & $y$ & 1853 \\
10 & 20.0 & $y$ & 4166 \\
11 & 25.0 & $y$ & 8224 \\
12 & 30.1 & $y$ & 14240 \\
\hline
\end{tabular}




\section{Spectral unfolding methods}

The spectrum unfolding code used with the multisphere measurement data was a greatly modified version of the iterative program TWOGO" developed by Hajnal. Spectral values were unfolded for both 12 and 20 TWOGO iterations. Calculated output errors for each iteration group did not show significant differences, so spectra contained in this report represent converged data determined after 20 iterations.

\section{Experimental setup}

Four special carts were constructed to serve as mobile platforms for measurements throughout the Plutonium Facility. Suspended from each cart were three spheres having alternating large and small diameters chosen to minimize scatter and maximize the isotropic response of each detector. Aluminum rod supports bolted to the top of each cart held the spheres so that their centers were $50 \mathrm{~cm}$ apart and located at a height of $1.5 \mathrm{~m}$ free in air. To minimize associated microphonics, nylon rope was used to attach each sphere to its upper rod support. Detector heights were chosen to match the locations of glovebox extremity ports constructed throughout this facility. The electronics used with this system were contained in air-cooled compartments located at the bottom of each cart. Each ${ }^{10} \mathrm{BF}_{3}$ detector operated at a potential of $+700 \mathrm{~V}$ and was connected to a Canberra 2006 preamplifier and Ortec 572 amplifier. Signals were processed through an optional Nuclear Data ND-588 multiplexer and sent to a portable computer containing an AccuSpec " $A$ " acquisition data board operating AccuSpec MCA software. ${ }^{12}$ Spectral data were acquired such that the overall statistical error for converged spectra was less than $3 \%$. These measurements required 60 -s counts in material storage areas and 1200-s for hall corridors. Total time for each measurement characterization ranged from 0.25 to $4.3 \mathrm{~h}$.

\section{Measurements}

Glovebox equipment and source geometries that surrounded the majority of our measurement positions constrained our ability to properly multiplex detector signals. Thus, we acquired spectral information using each detector positioned at exactly one spatial location until all sphere responses were recorded. Our measurements concentrated on overall facility opcrations that imparted neutrons at (i) significant fluence rates and/or high-use factor areas, (ii) key process sites in routine use, and (iii) special nuclear material (SNM) storage/project areas. The majority of our measurements were conducted throughout the Plutonium Facility without prior notice.

During dynamic processes, including hydrofluorination, the Ebeline neutron rem detector (NRD) ${ }^{13}$ was operated at one location to scale counts throughout each sphere measurement. These values were to be used to normalize the measurement data if the fluence rate changed over the measurement interval by greater than $15 \%$. The NRD monitor results remained constant throughout these measurements. Within the resolution of the NRD, normalization of the multisphere data was not required. Understanding the response of the NRD in field environments was crucial to using this instrument as a reference remmeter to monitor fluence or dose-equivalent rates imparted throughout various process areas at the Plutonium Facility.

Using the NRD in field environments with a significant degree of confidence required the measurement of its calibration neutron spectrum. Likewise, all past neutron correction factors measured for this facility relied on the NRD as the primary reference dosimeter. For these reasons, our first spectral measurements were acquired at the LANL Neutron Well Calibration Facility where NRD calibrations are performed using a ${ }^{239} \mathrm{Pu}-\mathrm{Be}$ source positioned in a concrete well. Upon unfolding the measured Neutron Well calibration spectrum, measurements at six general areas in the Plutonium Facility were performed: $(i)$ ${ }^{238} \mathrm{Pu}$ heat source processing, (ii) plutonium isotope recovery and precipitation, (iii) plutonium isotope evaporation, (iv) plutonium hydrofluorination, $(v)$ metal storage, and $(v i)$ hall corridors designated as "safe havens."

\section{Dosimeter and remmeter folded response values}

Response values for bare and albedo ${ }^{\circ} \mathrm{LiF}$ TLDs, track-etch CR-39, BDI-100 bubble detectors, NTA film, and for the remmeters NRD and Snoopy were obtained from published sources. ${ }^{1416}$ There was not a one-to-one correspondence between the published dosimeter/remmeter response values when they were compared to the 27 energy groups used by TWOGO. Thus, a smoothing and intc.polation program originally written by Pachner ${ }^{17}$ was modified to calculate response values for each dosimeter and remmeter so they would be compatible with the $27 \log$-log interpolated energy-group midpoint values calculated by TWOGO. The following equations were used to calculate dosimeter and remmeter response values:

$$
\bar{R}=\frac{\int_{\min }^{E_{\max }} N(E) R(E) d E}{\int_{E_{\min }}^{E_{\max }} N(E) d E}
$$

$$
\bar{f}=\frac{\int_{E_{\min }}^{E_{\max }} N(E) f(E) d E}{\int_{E_{\min }}^{E_{\max }} N(E) d E}
$$


where $\bar{R}$ is the average response of the dosimeter or remmeter (response $\left.\mathrm{cm}^{2}\right), \mathrm{N}(\mathrm{E})$ is the differential neutron fluence rate $\left(\mathrm{n} / \mathrm{cm}^{2} / \mathrm{s} / \mathrm{MeV}\right), R(E)$ is a detector response value for a given neutron energy ${ }^{1416}$ modified to be compatible with TWOGO (response per unit fluence), $\overline{\mathrm{f}}$ is the average spectrum-weighted fluence-to-dose-equivalent conversion factor $\left(0.01 \times \mathrm{mSv} \mathrm{cm}{ }^{2}\right)$ and $f(E)$ is the fluence-to-dose-equivalent conversion values from NCRP $38^{\prime \prime}\left(0.01 \times \mathrm{mSv} \mathrm{cm}{ }^{2}\right)$. The average dosimeter or remmeter response calculated for each spectra, $\bar{R}_{d}$ [counts/ $(0.01 \times \mathrm{mSv})]$, was cietermined as the quotient of equation 1 to equation 2. For these calculations the factor of $0.01 \times \mathrm{mSv}$ was used because it is directly equivalent to the non-SI unit of mrem.

\section{Impact of KCAP 60 rocommendations}

In an attempt to estimate the health risk impact of implementing ICRP 60 recommendations at the Plutonium Facility, calculations were performed on relevant neutron spectra shown in this report. These results are offered $(i)$ so that putative upgrades in personnel neutron dosimetry at this facility can be planned and (ii) to serve as a reference showing where current DOE standards are in relation to the international community standards.

Currently, DOE Order $5480.11^{19}$ lists the fluence-to-doseequivalent conversion factors, and, hence, $Q$ values assigned for use at LANL. These values were taken from NCRP 38 and are also listed in ANSI/ANS-6.1.1-1977. ${ }^{20}$ There is a general consensus among many radiation protection disciplines that the average $Q$ value for fission-produced neutrons should be raised from 10 to 20, and such recommendations to effectively double the $Q$ value are being considered by the DOE. For examplc, the DOE recently published the Radiological Control Manual, ${ }^{21}$ which states that a "neutron quality factor of 20 should be used for design purposes." European and other countries have already adopted ICRP $60^{22}$ recommendations, which imply an assessment using radiation weighting factors $\left(w_{R}\right)$ in place of $Q$. $Q$ values are based on the linear energy transfer (LET), while $w_{R}$ values are related to the relative biological effectiveness (RBE) of the radiation.

The relative difference between $w_{R}$, the absorbed dose averaged over a tissue or organ (rather than a point) and weighted for the radiation quality that is of interest, and $Q$ have been calculated for an infinitesimally small volume of tissue. For these conditions, comparison between average $w_{R}\left(\bar{w}_{R}\right)$ and average $Q$ values $(\bar{Q})$ is possible. These parameters are mathematically defined as follows:

$$
\begin{gathered}
\bar{w}_{R}=\frac{\int_{E_{\min }}^{E_{\max }} w_{R}(E) H(E) d E}{\int_{E_{\min }}^{E_{\max }} H(E) d E} \\
\bar{Q}=\frac{1}{D} \int_{E_{\min }}^{E_{\max }} Q(L) D(L) d L
\end{gathered}
$$

where $H(E), D, D(L)$, and $Q(L)$ are the energy-dependent dose equivalent, the absorbed dose in tissue, the LET-dependent absorbed dose in tissue and the LET-dependent quality factor, respectively. All $w_{R}(E)$ values were calculated using the ICRP 60 mathematical relationship:

$$
w_{R}=5+17 e^{-\left[\ln \left(2 E_{n}\right)\right]^{2} / 6}
$$

where $E_{\mathrm{n}}$ represents the neutron energy in $\mathrm{MeV} . \mathrm{H}(\mathrm{E})$ values were calculated by folding ANSI/ANS 6.1.1-1977 fluence-todose-equivalent conversion factors into the neutron number and energy-weighted $N(E)$ dE distributions calculated by TWOGO for each measured spectrum. The product $D(L) d L$ is the absorbed dose in tissue for the LET interval $\mathrm{L}$ to $\mathrm{L}+\mathrm{dL}$ at a point in space that was also calculated by TWOGO. 


\section{RESULTS}

\section{Multlsphere measurement errors}

Unfolded calibration measurement errors calculated after 20 TWOGO iterations ranged from $0.12 \%$ for a bare ${ }^{252} \mathrm{Cf}$ source to $2.1 \%$ for glovebox simulated spectra. Unfolded spectral errors calculated after 20 iterations for the combined 12 Plutonium Facility multisphere measurements were less than $3 \%$. The average error and standard error of the mean (SEM) determined for these field measurements was $2.2 \% \pm 0.11 \%$. The high and low values representing this distribution are $2.9 \%$ and $1.1 \%$.

\section{Multisphere system callbration}

The multisphere system and associated electronics were calibrated in a low-scatter facility at EML, using bare ${ }^{252} \mathrm{Cf}$ before their delivery to LANL and then upon their return trip to New York. These calibrations were essentially identical to the unfolded spectrum for this system published by Liu et al ${ }^{6}$ These spectra were indistinguishable from the EML unfolded, 27 energy group, input spectrum shown in Figure 1. In fact, the integral quantities of fluence rate, dose-equivalent rate, average $Q$, and average neutron energy determined for the measured spectrum were within $2 \%$ to $3 \%$ of reference values. ${ }^{14}$ Unfolding the bare ${ }^{252} \mathrm{Cf}$ calibration spectrum resulted in values of $39.6 \mathrm{n} / \mathrm{cm}^{2} / \mathrm{s}, 47.9 \mu \mathrm{Sv} / \mathrm{h}, 9.23$, and $2.23 \mathrm{MeV}$, respectively. All calculations unless otherwise stated utilized the fluence-to-dose-equivalent conversions published in ANSI/ ANS-6.1.1-1977. These values were taken from ICRP 38 and are required for use by DOE Order 5480.11 .

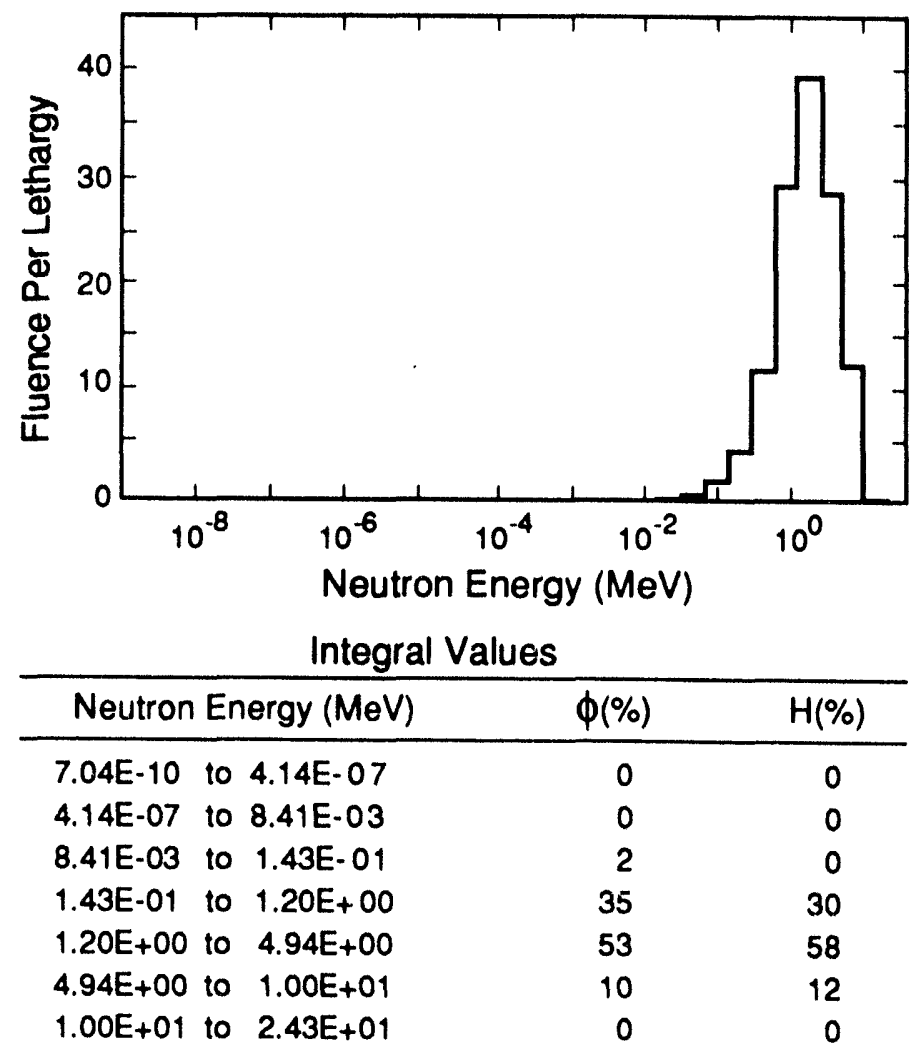

Figure 1. Calibration neutron spectrum of a bare ${ }^{252} \mathrm{Cf}$ source $(\bar{E}=2.23 \mathrm{MeV} ; \dot{H}=47.9 \mu \mathrm{Sv} / \mathrm{h}$ ).

\section{Glovebox simulated spectra}

Most gloveboxes having significant neutron dose rates throughout the Plutonium Facility are shielded using $10.2 \mathrm{~cm}$ of Lucite. At heights below about $1 \mathrm{~m}$, a significant number of gloveboxes also contain 10.2-cm-thick side compartments that are filled with hydrogenous liquid as a substitute for further Lucite shielding. To experimentally simulate glovebox shielding, $10.2 \mathrm{~cm}$ of Lucite was positioned in front of a bare ${ }^{232} \mathrm{Cf}$ source in a LANL low-scatter calibration facility. Two spectra were measured for this shielding geometry. The first spectrum was measured for a source-to-detector-midpoint distance of $1.5 \mathrm{~m}$ and is shown in Figure 2. For these measurements a DOE Laboratory Accreditation Program (DOELAP) standard, $40 \times 40 \times 15 \mathrm{~cm}^{3}$ Lucite phantom, was positioned parallel touching the back of each sphere, so that measurements would simulate conditions during the anterior irradiation of a dosimeter mounted on a human body. The integral quantities of fluence rate, dose-equivalent rate, average $Q$, and average neutron energy determined for this geometry were $650 \mathrm{n} / \mathrm{cm}^{2} / \mathrm{s}$, $240 \mu \mathrm{Sv} / \mathrm{h}, 7.21$, and $1.12 \mathrm{MeV}$, respectively. To simulate the posterior irradiation of a dosimeter, the Lucite phantom was repositioned without changing the $1.5-\mathrm{m}$ source-to-detector distance in front of each detector. The measured spectrum for the posterior simulation is shown in Figure 3. The integral quantities of fluence rate, dose-equivalent rate, average $Q$, and average neutron energy determined for this geometry were $60.3 \mathrm{n} / \mathrm{cm}^{2} / \mathrm{s}$, 
$33.2 \mu \mathrm{Sv} / \mathrm{h}, 7.91$, and $1.49 \mathrm{MeV}$, respectively. These measurements were compared to a $10^{7}$ history simulation performed using the Monte Carlo neutron photon transport code MCNP4/ $\mathrm{PC}_{,}{ }^{23}$ which showed that the EML system was in working order (i.e., calculated anterior and posterior average neutron energies were $1.15 \pm 0.015 \mathrm{MeV}$ and $1.58 \pm 0.058 \mathrm{MeV}$, respectively). After the multisphere calibration measurements and MCNP calculations were shown to be in agreement, the EML system was moved first to the LANL Neutron Well Calibration Facility, where reference dosimeter calibrations of the NRD are performed, and then to the Plutonium Facility for field characterizations.

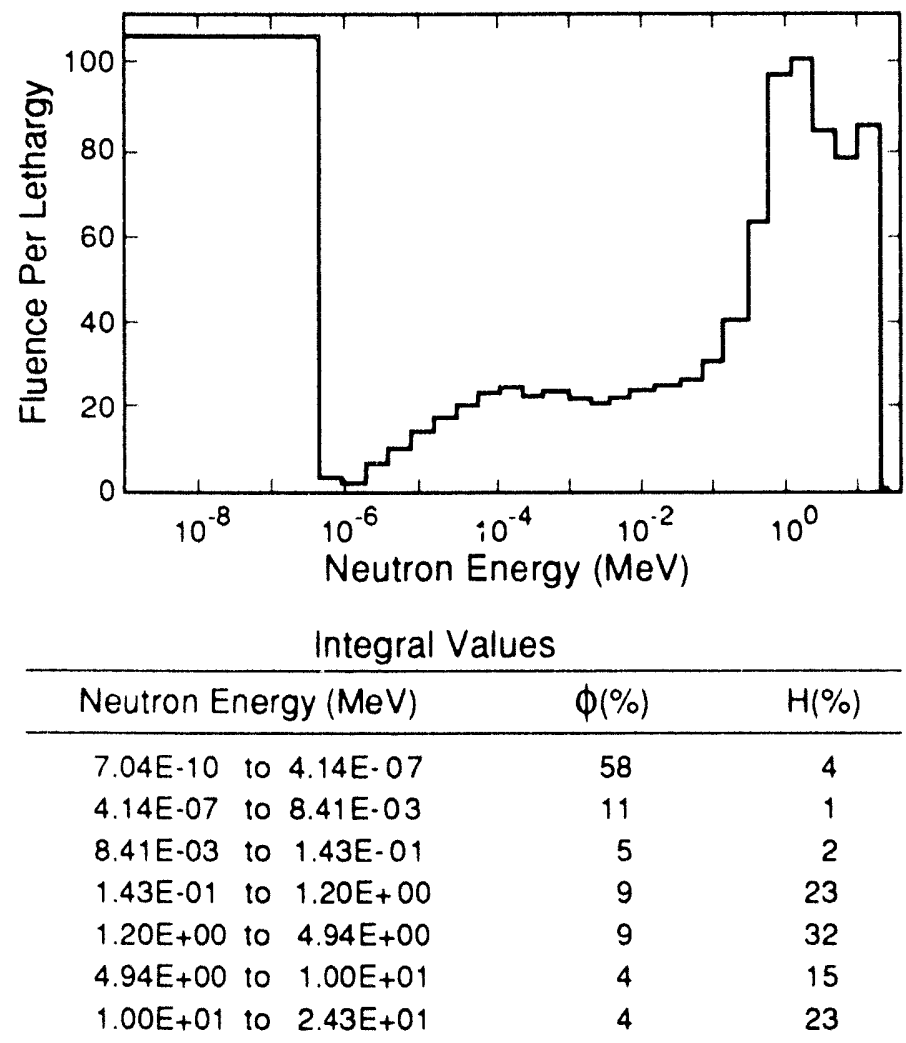

Figure 2. Neutron spectrum representing the anterior irradiation of a dosemeter in a simulated glovebox geometry containing $10.2 \mathrm{~cm}$ Lucite shielding ( $\bar{E}=1.12 \mathrm{MeV} ; \dot{H}=240 \mu \mathrm{Sv} / \mathrm{h})$.

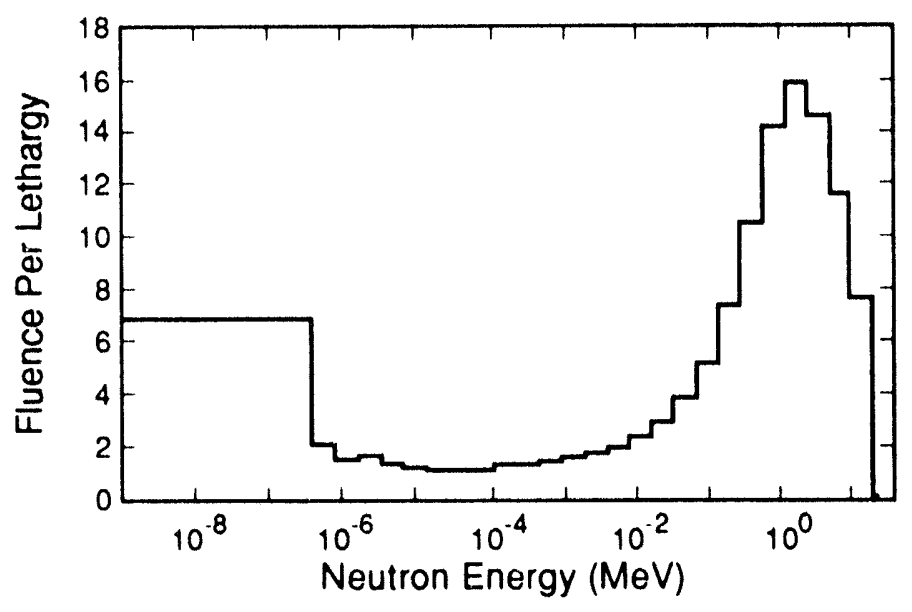

Integral Values

\begin{tabular}{ccc}
\hline Neutron Energy (MeV) & $\phi(\%)$ & $H(\%)$ \\
\hline $7.04 E \cdot 10$ to $4.14 E \cdot 07$ & 40 & 2 \\
$414 E 07$ to $8.41 E-03$ & 10 & 1 \\
$841 E-13$ to $143 E-01$ & 7 & 2 \\
$1.43 E=1$ to $120 E+00$ & 17 & 27 \\
$120 E+6$ to $4.94 E+00$ & 16 & 37 \\
$494 E+3$ to $100 E+01$ & 6 & 16 \\
$1.00 E+01$ to $243 E+01$ & 4 & 15
\end{tabular}

Figure 3. Neutron spectrum representing the posterior irradiation of a dosemeter in a simulated glovebox geometry containing $10.2 \mathrm{~cm}$ Lucite shielding ( $\bar{E}=1.49 \mathrm{MeV} \mathrm{MeV} ; \dot{H}=33.2 \mu \mathrm{Sv} / \mathrm{h}$ ).

\section{Neutron well reference spectrum}

Reference neutron dosimetry measurements at LANL utilize a 22.8-cm NRD, which is calibrated using a ${ }^{239} \mathrm{Pu}-\mathrm{Be}$ source positioned in a concrete well.' Energy-compensating corrections determined for various source-to-detector distances in this highscatter environment are made using Munte Carlo calculations. ${ }^{\text {is }}$ Spectral measurements of the ${ }^{239} \mathrm{Pu}$-Be well source were performed using the EML multisphere system. Results of these measurements are shown in Figure 4. The source-to-detectorcenter distances for all spheres were held constant at $119.2 \mathrm{~cm}$ and consisted of a 100-cm source-to-well-surface distance plus an additional $19.2 \mathrm{~cm}$ distance in air, required to position the $15.2-\mathrm{cm}$-radius sphere on a $4-\mathrm{cm}$-high aluminum holding ring. The neutron well diameter, being fixed at $38.1 \mathrm{~cm}$, approached the diameter of the $30.5-\mathrm{cm}$ sphere and was believed to adversely bias this measurement. Because of competing geometrical constraints, an alternative method of estimating the $30.5 \cdot \mathrm{cm}$ sphere response for the neutron well measurements was conceived and applied to these measurements. This unfolding method is discussed in detail in a corresponding note submitted for publication. The integral quantities of fluence rate, dose equivalent rate, average $Q$, and average neutron energy determined for the neutron well spectrum were $256 \mathrm{n} / \mathrm{cm}^{2} / \mathrm{s}$, $243 \mu \mathrm{Sv} / \mathrm{h}, 8.17$, and $2.28 \mathrm{MeV}$, respectively. 


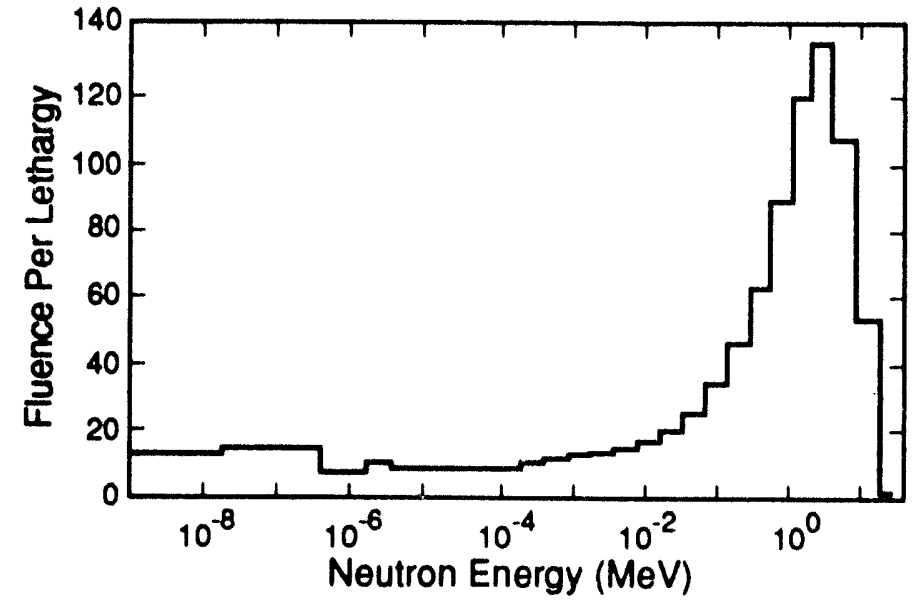

Integral Values

\begin{tabular}{lcc}
\hline Neutron Energy $(\mathrm{MeV})$ & $\phi(\%)$ & $\mathrm{H}(\%)$ \\
\hline $7.04 \mathrm{E}-10$ to $4.14 \mathrm{E}-07$ & 16 & 0 \\
$4.14 \mathrm{E}-07$ to $8.41 \mathrm{E}-03$ & 14 & 1 \\
$8.41 \mathrm{E}-03$ to $1.43 \mathrm{E}-01$ & 9 & 2 \\
$1.43 \mathrm{E}-01$ to $1.20 \mathrm{E}+00$ & 20 & 22 \\
$1.20 \mathrm{E}+00$ to $4.94 \mathrm{E}+00$ & 25 & 42 \\
$4.94 \mathrm{E}+00$ to $1.00 \mathrm{E}+01$ & 11 & 19 \\
$1.00 \mathrm{E}+01$ to $2.43 \mathrm{E}+01$ & 5 & 14
\end{tabular}

Figure 4. Neutron spectrum of the ${ }^{230} \mathrm{Pu}-\mathrm{Be}$ neutron calibration well used to calibrate the NRDs that are used to determine TLD neutron correction factors $(\bar{E}=2.28 \mathrm{MeV} ; \dot{H}=243 \mu \mathrm{Sv} / \mathrm{h})$.

\section{Plutonium Facillty spectra}

A composite floor plan of the Plutonium Facility is shown in Figure 5. Twelve spectra were measured throughout this facility, assessing six unique operations. These operations include ${ }^{239} \mathrm{Pu}$ heat source fabrication, Pu metal preparation and hydrofluorination, Pu metal precipitation, evaporation, the vault area (e.g., SNM storage), and various hallways designated as laboratory access corridors. Before multisphere measurements were carried out within the Plutonium Facility, a series of NRD, 7.62-cm Cd-coated sphere, bare ${ }^{10} \mathrm{BF}_{3}$ detector, Cd-shielded ${ }^{10} \mathrm{BF}_{3}$, and ionization measurements were conducted' throughout this facility to identify sites that meet conditions outlined for the spectral measurements described in the above measurements section. These detectors were also used following each multisphere measurement to allow for a conventional comparison of these data.

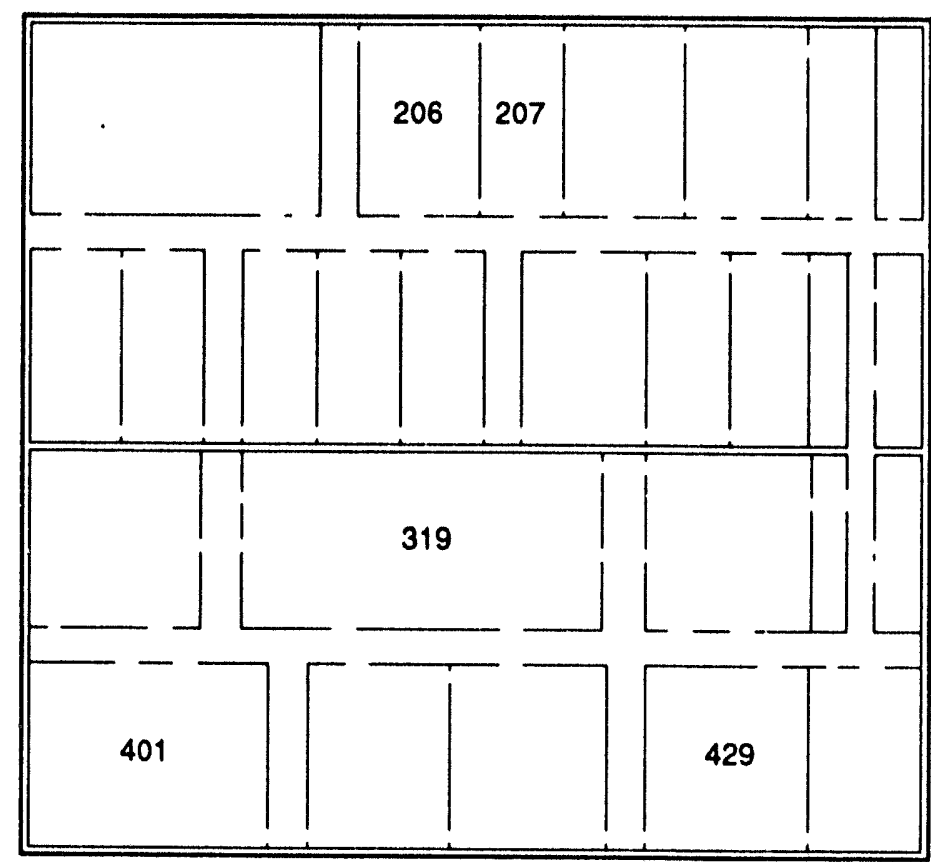

Figure 5. Composite floor plan of the LANL. Plutonium Facility.

\section{a) Heat source fabrication}

In the assembly of RTG heat sources, various operations are performed to process ${ }^{239} \mathrm{Pu}$. ${ }^{24,25}$ These processes include $(i)$ an ${ }^{16} \mathrm{O}$ exchange treatment to decrease the ${ }^{17} \mathrm{O}$ and ${ }^{18} \mathrm{O}$ content and reduce the rate of neutron emissions that occur by $(\alpha, n)$ reactions (reductions in neutron emission rates on a per unit mass basis following this procedure are typically four-to- five fold), (ii) ball milling to normalize incoming fuel particle size, (iii) granulation of fuel powder, (iv) seasoning or firing of granules at either $1100^{\circ} \mathrm{C}$ or $1600^{\circ} \mathrm{C},(v)$ hot pressing of conditioned granules into heat source pellets, (vi) encapsulation of pellets in clads, (vii) decontamination of fueled clads, and (viii) nondestructive testing of fueled clads followed by preparation for shipment. Heat sources are produced in an assembly-line manner, and these processes often occur simultaneously. For these reasons, multisphere measurements conducted in the ${ }^{238} \mathrm{Pu}$ areas do not necessarily represent steady-state processes. Each spectral measurement was significantly influenced by high-yield sources that were located in close proximity to the detectors during a specific measurement. In all measurements these sources inherently represented a localized process throughout the measurement interval. During each measurement the local sources were stationary, and measurements reflected the neutron spectrum for an observer standing near the process glovebox. 
The measured spectrum for the ball milling process is shown in Figure 6. The integral quantities of fluence rate, dose equivalent rate, average $Q$, and average neutron energy determined for this spectrum were $62.0 \mathrm{n} / \mathrm{cm}^{2} / \mathrm{s}, 20.7 \mu \mathrm{Sv} / \mathrm{h}, 7.60$, and $0.593 \mathrm{MeV}$, respectively. The measured spectrum for the firedgranules process is shown in Figure 7. Calculated values of fluence rate, dose equivalent rate, average $Q$, and average neutron energy determined for this spectrum were $41.0 \mathrm{n} / \mathrm{cm}^{2} / \mathrm{s}$, $13.0 \mu \mathrm{Sv} / \mathrm{h}, 7.52$, and $0.546 \mathrm{MeV}$, respectively. A comparison of the fired granules and the ball milling spectra show that both processes result in similar spectral quantities.

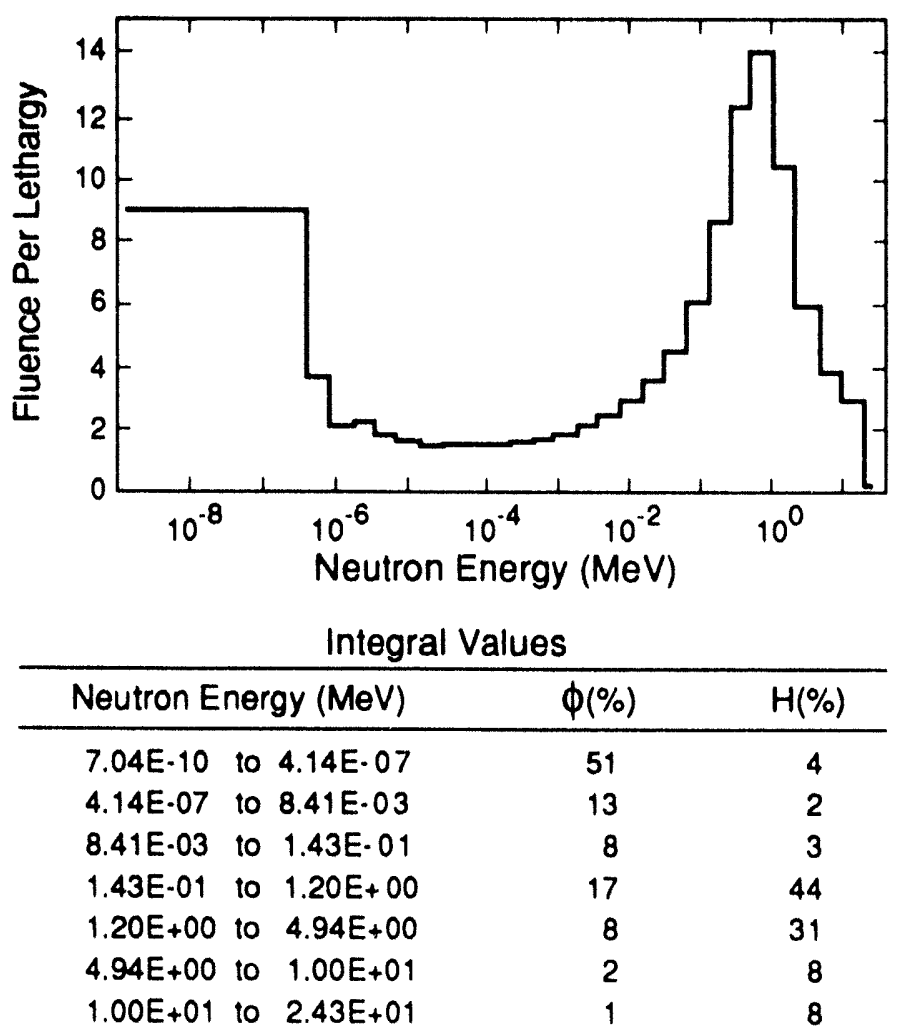

Figure 6. Neutron spectrum of the ${ }^{238} \mathrm{Pu}$ ball milling process $(\bar{E}=0.593 \mathrm{MeV} ; \dot{H}=20.7 \mu \mathrm{Sv} / \mathrm{h}$ ).

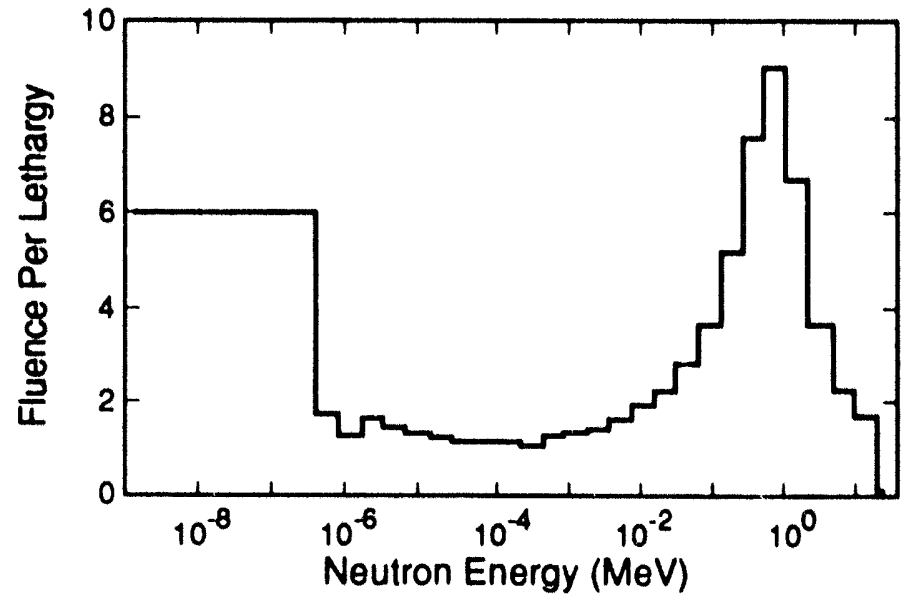

\begin{tabular}{ccc}
\multicolumn{4}{c}{ Integral Values } \\
\hline Neutron Energy (MeV) & $\phi(\%)$ & $H(\%)$ \\
\hline $7.04 E-10$ to $4.14 E-07$ & 52 & 4 \\
$4.14 E-07$ to $8.41 E-03$ & 14 & 2 \\
$8.41 E-03$ to $1.43 E-01$ & 8 & 3 \\
$1.43 E-01$ to $1.20 E+00$ & 16 & 44 \\
$1.20 E+00$ to $4.94 E+00$ & 7 & 32 \\
$4.94 E+00$ to $1.00 E+01$ & 2 & 7 \\
$1.00 E+01$ to $2.43 E+01$ & 1 & 8
\end{tabular}

Figure 7. Neutron spectrum of the ${ }^{23 e} \mathrm{Pu}$ fired granules process $(\bar{E}=0.546 \mathrm{MeV} ; \dot{H}=13.0 \mu \mathrm{Sv} / \mathrm{h})$.

Located within the heat source fabrication area was a $10.2-\mathrm{cm}$ thick Lucite-shielded glovebox that contained a $3.721 \pm 0.038-\mathrm{cm}$ diameter sphere $(250 \mathrm{~g})$ of ${ }^{230} \mathrm{PuO}_{2}$ fuel (isotopic content approximately $80 \%{ }^{23} \mathrm{Pu}$ ) maintained at about $1000^{\circ} \mathrm{C}$ by a removable thermal isolation cover. ${ }^{2627}$ This source, shown in Figure 8, glows bright red because of its near-100-thermal-watt output and was manufactured as part of the past multihundred-watt heat source program. Before these measurements were taken, this source was used for demonstrating a visual perspective of the thermal output energy generated in the process of heat source nuclear decay. The back side of this glovebox contained less overall hydrogenous shielding than its front surface and, thus, was a concem for the Nuclear Materials Technology staff in their pursuit of ALARA goals. Health and safety concerns for work that was intermittently conducted in this generalized area prompted a series of multisphere measurements to be made at these locations. Results of these measurements are shown for the front and rear glovebox locations in Figures 9 and 10, respectively. The integral quantities of fluence rate, dose equivalent rate, average $Q$, and average neutron energy determined for the front side of this glovebox were $79.2 \mathrm{n} / \mathrm{cm}^{2} / \mathrm{s}$, $26.3 \mu \mathrm{Sv} / \mathrm{h}, 7.6(\mathrm{)}$, and $0.589 \mathrm{McV}$, respectively. The integral quantities of fluence rate, dose equivalent rate, average $Q$, and average neutron energy determined for the back side of this glovebox were $94.0 \mathrm{n} / \mathrm{cm}^{2} / \mathrm{s}, 40.1 \mu \mathrm{Sv} / \mathrm{h}, 8.07$, and $0.758 \mathrm{MeV}$, respectively. These results clearly show that the back side of this glovebox represents a greater risk for workers than its front side. 
Photon measurements using a Radcal Corporation MDH-1515 ionization monitor coupled to a $180-\mathrm{cm}^{3}$ pancake probe ${ }^{2 \mathrm{~s}}$ were also taken at each of these locations and revealed exposure rates in excess of $0.80 \mathrm{mR} / \mathrm{h}$.

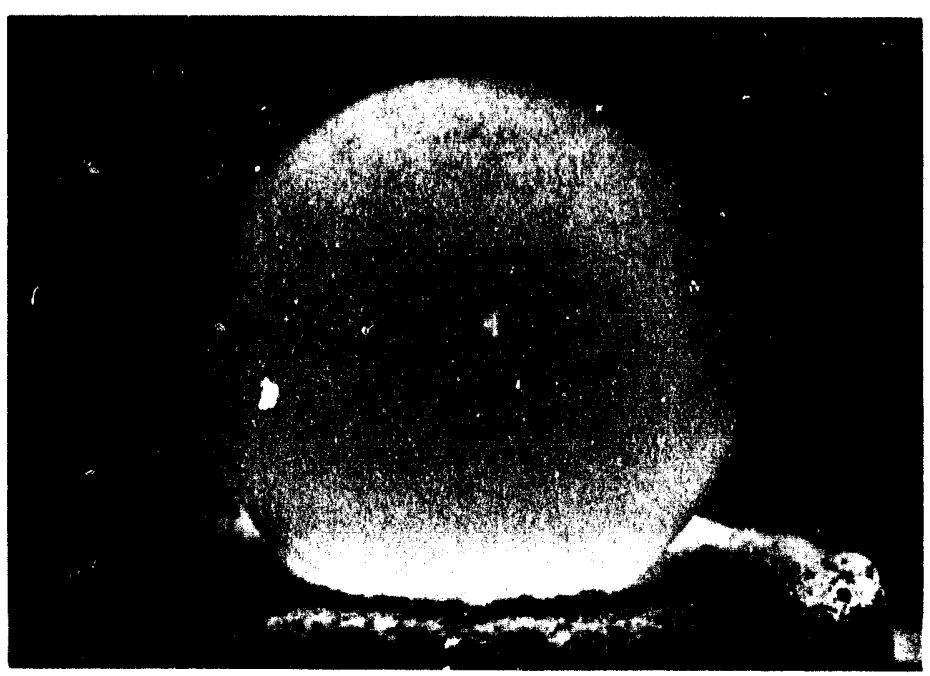

Figure 8. A 250-g source of ${ }^{230} \mathrm{PuO}_{2}$ surrounded by a graphite impact shell machined to generate $100 \pm 2 W$ thermal output.

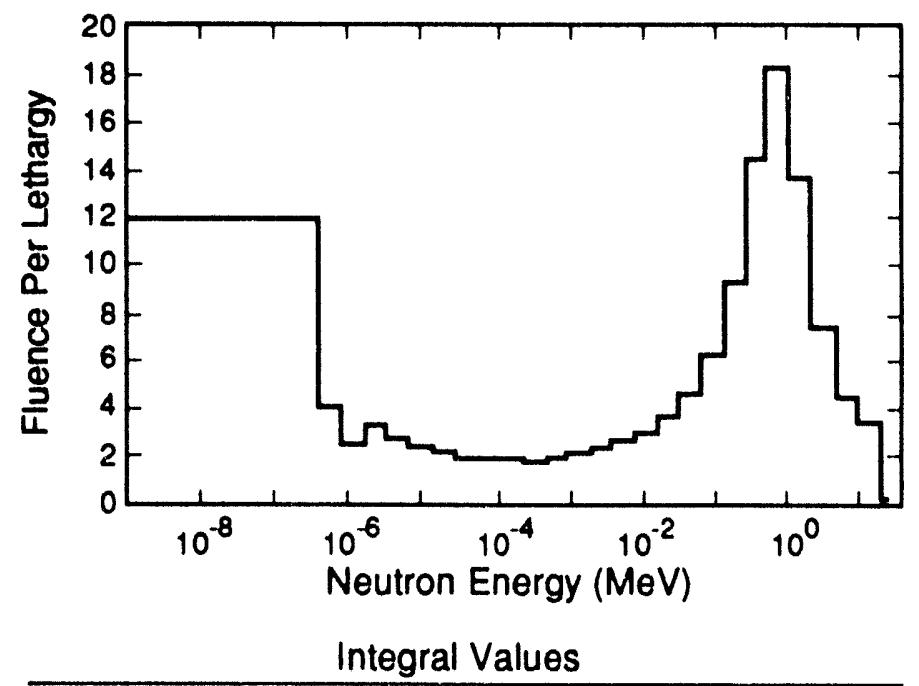

\begin{tabular}{|c|c|c|}
\hline Neutron Energy (MeV) & $\phi(\%)$ & $H(\%)$ \\
\hline $7.04 \mathrm{E}-10$ 10 $4.14 \mathrm{E}-07$ & 53 & 4 \\
\hline $4.14 \mathrm{E}-07$ to $8.41 \mathrm{E}-03$ & 13 & 2 \\
\hline $8.41 \mathrm{E}-03$ to $1.43 \mathrm{E}-01$ & 7 & 3 \\
\hline $1.43 E-01$ to $1.20 E+00$ & 16 & 43 \\
\hline $1.20 E+\infty 0$ to $4.94 E+00$ & 8 & 32 \\
\hline $4.94 E+00$ to $1.00 E+01$ & 2 & 8 \\
\hline $1.00 E+01$ to $2.43 E+01$ & 1 & 8 \\
\hline
\end{tabular}

Figure 9. Neutron spectrum of the ${ }^{238} \mathrm{PuO}_{2}$ heat source sphere measured in front of its containment glovebox $(\bar{E}=0.589 \mathrm{MeV}$; $\dot{H}=26.3 \mu \mathrm{S} v(\mathrm{M})$.

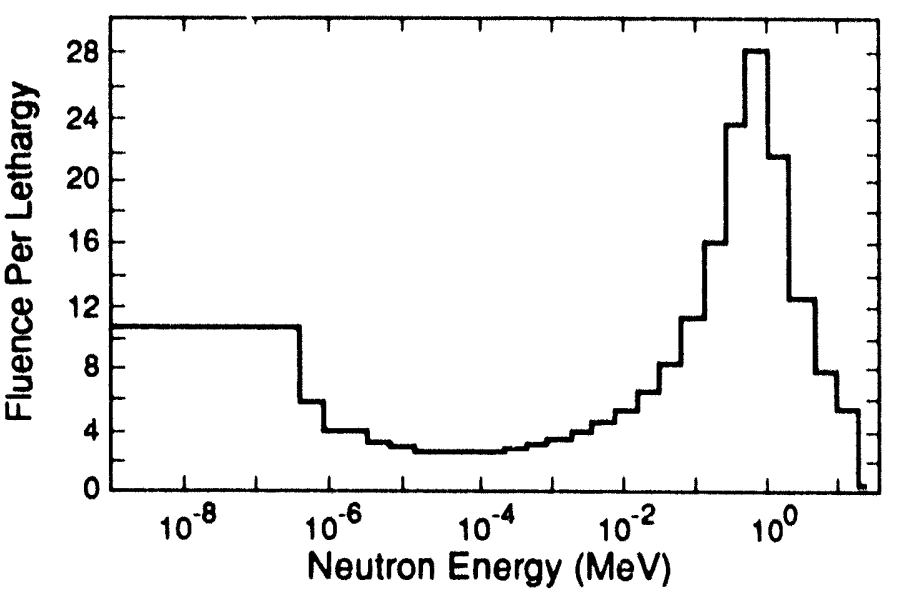

Integral Values

\begin{tabular}{cccc}
\hline Neutron Energy $(\mathrm{MeV})$ & $\phi(\%)$ & $\mathrm{H}(\%)$ \\
\hline $7.04 \mathrm{E}-10$ to & $4.14 \mathrm{E} \cdot 07$ & 40 & 2 \\
$4.14 \mathrm{E}-07$ to $8.41 \mathrm{E}-03$ & $1+$ & 1 \\
$8.41 \mathrm{E}-03$ to & $1.43 \mathrm{E}-01$ & 10 & 3 \\
$1.43 \mathrm{E}-01$ to $1.20 \mathrm{E}+00$ & 22 & 45 \\
$1.20 \mathrm{E}+00$ to $4.94 \mathrm{E}+00$ & 11 & 33 \\
$4.94 \mathrm{E}+00$ to $1.00 \mathrm{E}+01$ & 2 & 8 \\
$1.00 \mathrm{E}+01$ to $2.43 \mathrm{E}+01$ & 1 & 8
\end{tabular}

Figure 10. Neutron spectrum of the ${ }^{234} \mathrm{PuO}_{2}$ heat source sphere measured in back of its containment glovebox $(\bar{E}=0.758 \mathrm{MeV}$; $\dot{H}=40.1 \mu \mathrm{Sv} / \mathrm{h}$ ).

For ALARA purposes (e.g., a savings of $40.1 \mu \mathrm{Sv} / \mathrm{h}$ neutron and $6.95 \mu \mathrm{Sv} / \mathrm{h}$ photon), this source was removed from the working area and is no longer a radiation protection concern.

\section{b) Motal preparation and hydrofluorination}

The hydrofluorination of ${ }^{239} \mathrm{PuO}_{2}$ results in increased, yet variable, neutron emission rates and lower average neutron energies primarily from $(\alpha, n)$ reactions with fluorine. A period exists towards the end of this process when most of the matcrial has been chemically transformed, resulting in essentially constant neutron emission rates at a constant average energy. Our measurements were acquired during this period of chemical stability, and an attempt to monitor for changes in neutron fluence for each measurement was made using the NRD operating in the scaler mode. These crude measurements were compared to temperature profiles monitoring this process and indicated that a chemical equilibrium had been maintained throughout our measurement period. The spectrum measured during this interval is shown in Figure 11. Other ${ }^{239} \mathrm{Pu}$ metal resided in close proximity to the hydrofluorination process and contributed to the results of these measurements. The integral quantities of fluence rate, dose equivalent rate, average $Q$, and average neutron energy determined for this location were $46.0 \mathrm{n} / \mathrm{cm}^{2} / \mathrm{s}, 11.6 \mu \mathrm{Sv} / \mathrm{h}, 7.06$, and $0.386 \mathrm{McV}$, respectively. 


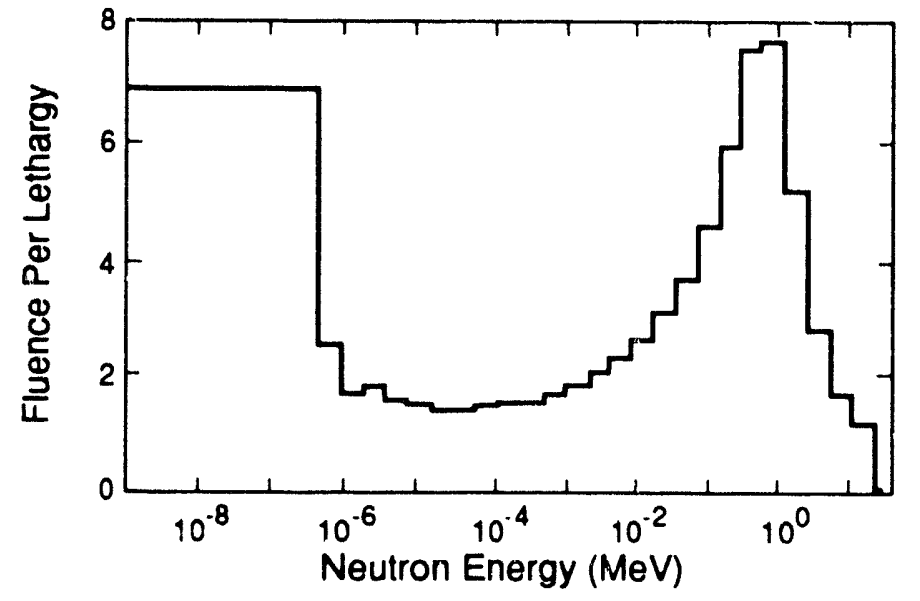

Integral Values

\begin{tabular}{crc}
\hline Neutron Energy (MeV) & $\phi(\%)$ & $H(\%)$ \\
\hline $7.04 \mathrm{E}-10$ to $4.14 \mathrm{E}-07$ & 53 & 6 \\
$4.14 \mathrm{E}-07$ to $8.41 \mathrm{E}-03$ & 16 & 2 \\
$8.41 \mathrm{E}-03$ to $143 \mathrm{E}-01$ & 9 & 5 \\
$1.43 \mathrm{E}-01$ to $1.20 \mathrm{E}+00$ & 14 & 47 \\
$1.20 \mathrm{E}+00$ to $4.94 \mathrm{E}+00$ & 6 & 28 \\
$4.94 \mathrm{E}+00$ to $1.00 \mathrm{E}+01$ & 1 & 6 \\
$1.00 \mathrm{E}+01$ to $2.43 \mathrm{E}+01$ & 1 & 6
\end{tabular}

Figure 11. Neutron spectrum of the hydrofluorination process $(\vec{E}=0.386 \mathrm{MeV} ; \dot{H}=11.6 \mu \mathrm{Sv} / \mathrm{h})$.

\section{c) Motal procipitation and evaporation}

These dissolution processes utilize various liquid-holding tanks, precipitators, and evaporators. Scrap metal was also present at this location and was used to feed the recovery effort. The measured spectrum representing the precipitation process is shown in Figure 12. The integral quantities of fluence rate, dose equivalent rate, average $Q$, and average neutron energy determined for the precipitation process were $28.0 \mathrm{n} / \mathrm{cm}^{2} / \mathrm{s}$, $21.3 \mu \mathrm{Sv} / \mathrm{h}, 8.76$, and $1.60 \mathrm{MeV}$, respectively. The integral quantities of fluence rate, dose equivalent rate, average $Q$, and average neutron energy determined for the evaporation process were $8.53 \mathrm{n} / \mathrm{cm}^{2} / \mathrm{s}, 5.74 \mu \mathrm{Sv} / \mathrm{h}, 8.65$, and $1.33 \mathrm{MeV}$, respectively. The spectrum measured for the evaporation process is shown in Figure 13. Each of these spectra show a relatively small thermal and epithermal neutron component.

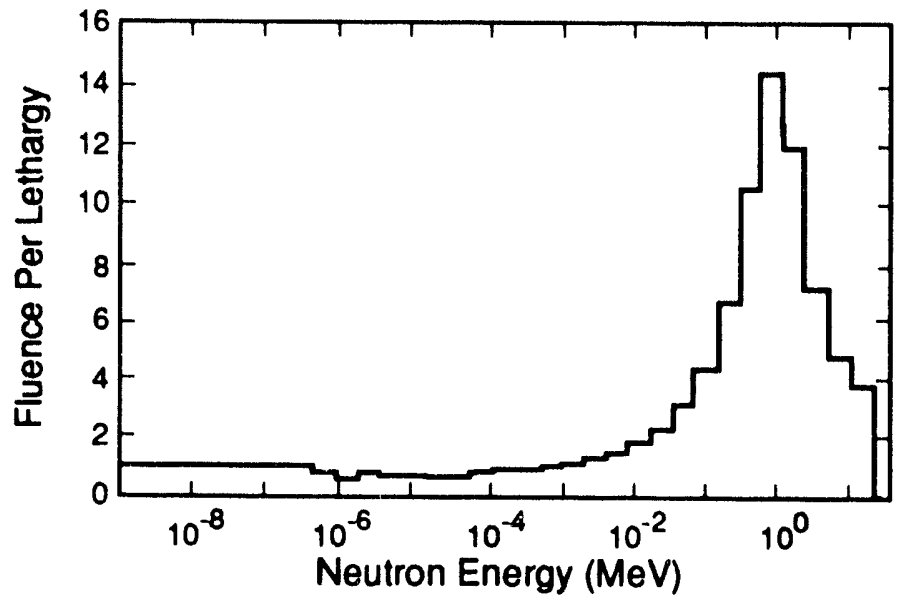

Integral Values

\begin{tabular}{ccc}
\hline Neutron Energy (MeV) & $\phi(\%)$ & $H(\%)$ \\
\hline $7.04 \mathrm{E}-10$ to $4.14 \mathrm{E}-07$ & 12 & 0 \\
$4.14 \mathrm{E}-07$ to $8.41 \mathrm{E}-03$ & 12 & 1 \\
$8.41 \mathrm{E}-03$ to $1.43 \mathrm{E}-01$ & 12 & 2 \\
$1.43 \mathrm{E}-01$ to $1.20 \mathrm{E}+00$ & 34 & 40 \\
$1.20 \mathrm{E}+00$ to $4.94 \mathrm{E}+00$ & 21 & 36 \\
$4.94 \mathrm{E}+00$ to $1.00 \mathrm{E}+01$ & 5 & 10 \\
$1.00 \mathrm{E}+01$ to $2.43 \mathrm{E}+01$ & 4 & 11
\end{tabular}

Flgure 12. Neutron spectrum of the precipitation process $(\bar{E}=1.60 \mathrm{MeV} ; \dot{H}=21.3 \mu \mathrm{SV} / \mathrm{h})$.

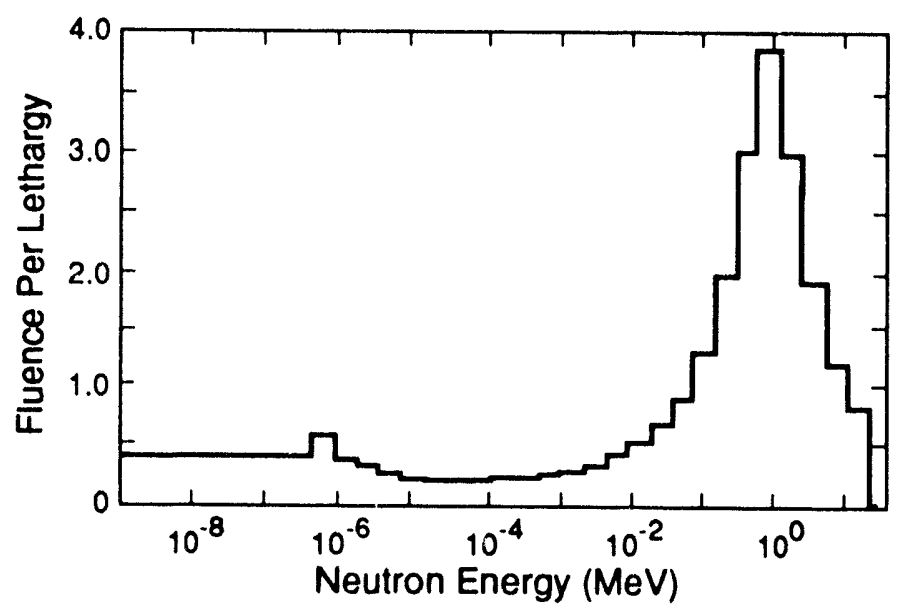

Integral Values

\begin{tabular}{ccc}
\hline Neutron Energy (MeV) & $\phi(\%)$ & $H(\%)$ \\
\hline $7.04 E-10$ to $4.14 \mathrm{E}-07$ & 16 & 1 \\
$4.14 \mathrm{E}-07$ to $8.41 \mathrm{E}-03$ & 15 & 1 \\
$8.41 \mathrm{E}-03$ to $1.43 \mathrm{E}-01$ & 12 & 2 \\
$1.43 \mathrm{E}-01$ to $1.20 \mathrm{E}+00$ & 32 & 42 \\
$1.20 \mathrm{E}+00$ to $4.94 \mathrm{E}+00$ & 18 & 36 \\
$4.94 \mathrm{E}+00$ to $1.00 \mathrm{E}+01$ & 4 & 9 \\
$1.00 \mathrm{E}+01$ to $2.43 \mathrm{E}+01$ & 3 & 9
\end{tabular}

Figure 13. Neutron spectrum of the evaporation process $(\bar{E}=1.33 \mathrm{MeV} ; \dot{H}=5.74 \mu \mathrm{S} v / \mathrm{h})$. 


\section{d) Material storage vault}

Various SNM are stored in a vault facility that was designed to be "criticality safe." Two spectral measurements were performed in this facility near doors $K$ and $D$ and are shown in Figures 14 and 15, respectively. The integral quantities of fluence rate, dose equivalent rate, average $Q$, and average neutron energy determined near door $K$ were $309 \mathrm{n} / \mathrm{cm}^{2} / \mathrm{s}$, $72.9 \mu \mathrm{Sv} / \mathrm{h}, 6.87$, and $0.349 \mathrm{MeV}$, respectively. The integral quantities of fluence rate, dose equivalent rate, average $Q$, and average neutron energy calculated near door $D$ were $548 \mathrm{n} / \mathrm{cm}^{2} / \mathrm{s}$, $152 \mu \mathrm{Sv} / \mathrm{h}, 7.24$, and $0.408 \mathrm{MeV}$, respectively. In the relatively short distance between these locations $(9 \mathrm{~m})$, significantly different neutron spectra were measured. The spectrum measured near door D was "harder" than that measured near door K. These spectral differences were expected and reflect differing SNM types and means for neutron moderation (i.e., ${ }^{238} \mathrm{Pu}$ moderated with hydrogenous liquid compared to ${ }^{239} \mathrm{Pu}-\mathrm{Be}$ moderated in hydrogenous solid material).

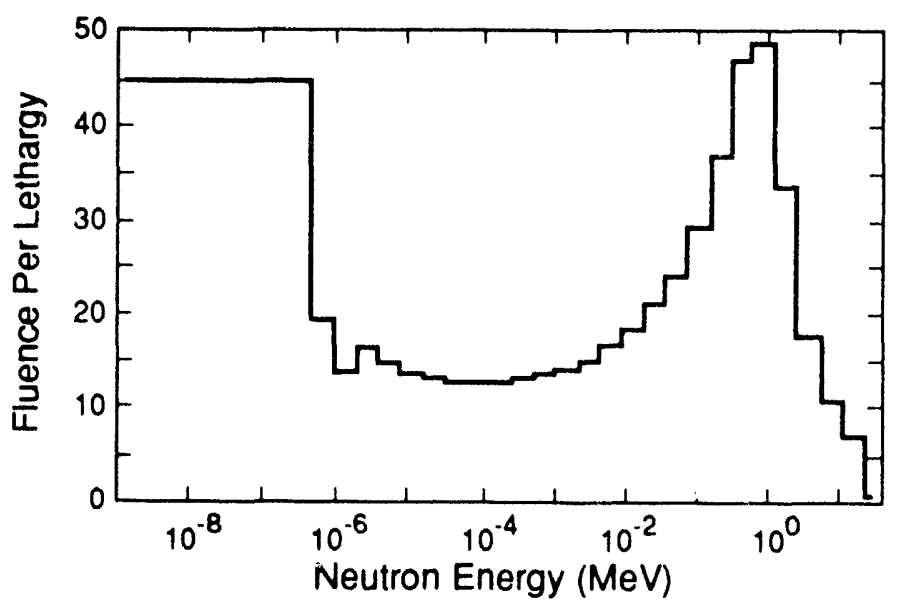

Integral Values

\begin{tabular}{cccc}
\hline Neutron Energy $(\mathrm{MeV})$ & $\phi(\%)$ & $H(\%)$ \\
\hline $7.04 \mathrm{E}-10$ to $4.14 \mathrm{E}-07$ & 51 & 6 \\
$4.14 \mathrm{E}-07$ to $8.41 \mathrm{E}-03$ & 20 & 3 \\
$8.41 \mathrm{E}-03$ to $1.43 \mathrm{E}-01$ & 9 & 5 \\
$1.43 \mathrm{E}-01$ to $1.20 \mathrm{E}+00$ & 13 & 46 \\
$1.20 \mathrm{E}+00$ to $4.94 \mathrm{E}+00$ & 5 & 28 \\
$4.94 \mathrm{E}+00$ to $1.00 \mathrm{E}+01$ & 1 & 6 \\
$1.00 \mathrm{E}+01$ to $2.43 \mathrm{E}+01$ & 1 & 6
\end{tabular}

Flgure 14. Neutron spectrum of SNM Vault $K$ $(\vec{E}=0.349 \mathrm{MoV} ; \dot{H}=72.9 \mu \mathrm{Sv} / \mathrm{h}$ ).

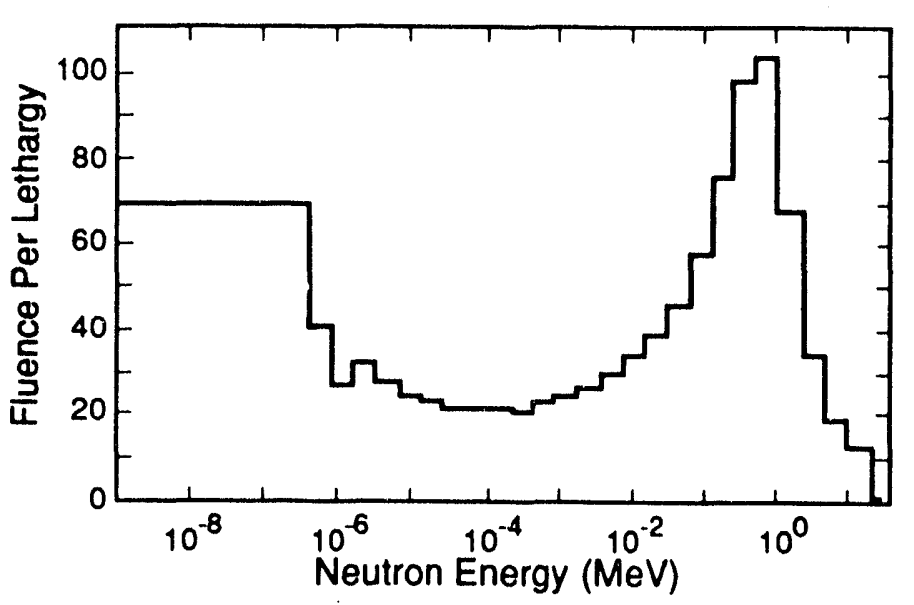

Integral Values

\begin{tabular}{ccc}
\hline Neutron Energy (MeV) & $\phi(\%)$ & $H(\%)$ \\
\hline $7.04 \mathrm{E}-10$ to $4.14 \mathrm{E}-07$ & 45 & 4 \\
$4.14 \mathrm{E}-07$ to $8.41 \mathrm{E}-03$ & 21 & 4 \\
$8.41 \mathrm{E}-03$ to $1.43 \mathrm{E}-01$ & 10 & 5 \\
$1.43 \mathrm{E}-01$ to $1.20 \mathrm{E}+00$ & 16 & 47 \\
$1.20 \mathrm{E}+00$ to $4.94 \mathrm{E}+00$ & 6 & 28 \\
$4.94 \mathrm{E}+00$ to $1.00 \mathrm{E}+01$ & 1 & 6 \\
$1.00 \mathrm{E}+01$ to $2.43 \mathrm{E}+01$ & 1 & 6
\end{tabular}

Figure 15. Neutron spectrum of SNM Vault $D$ $(\bar{E}=0.408 \mathrm{MeV} ; \dot{H}=152 \mu \mathrm{Sv} / \mathrm{h})$.

\section{e) Laboratory access corridors}

Neutron spectra measured in two hallways at opposite ends of the Plutonium Facility were nearly identical. These results are shown in Figures 16 and 17. The integral quantities of fluence rate, dose equivalent rate, average $Q$, and average neutron energy determined for the hall corridor outside of the ${ }^{238} \mathrm{Pu}$ processing rooms were $5.82 \mathrm{n} / \mathrm{cm}^{2} / \mathrm{s}, 1.09 \mu \mathrm{Sv} / \mathrm{h}, 6.34$, and $0.268 \mathrm{MeV}$, respectively. The integral quantities of fluence rate, dose equivalent rate, average $Q$, and average neutron energy determined for the hall corridor near Rooms 401 and 319 were $8.52 \mathrm{n} / \mathrm{cm}^{2} / \mathrm{s}, 1.41 \mu \mathrm{Sv} / \mathrm{h}, 5.92$, and $0.254 \mathrm{MeV}$, respectively. These results suggest that the Plutonium Facility containment acts as a massive cubical concrete moderator in which the sum of all neutron sources within its domain contribute to an average hallway energy and flux density. 


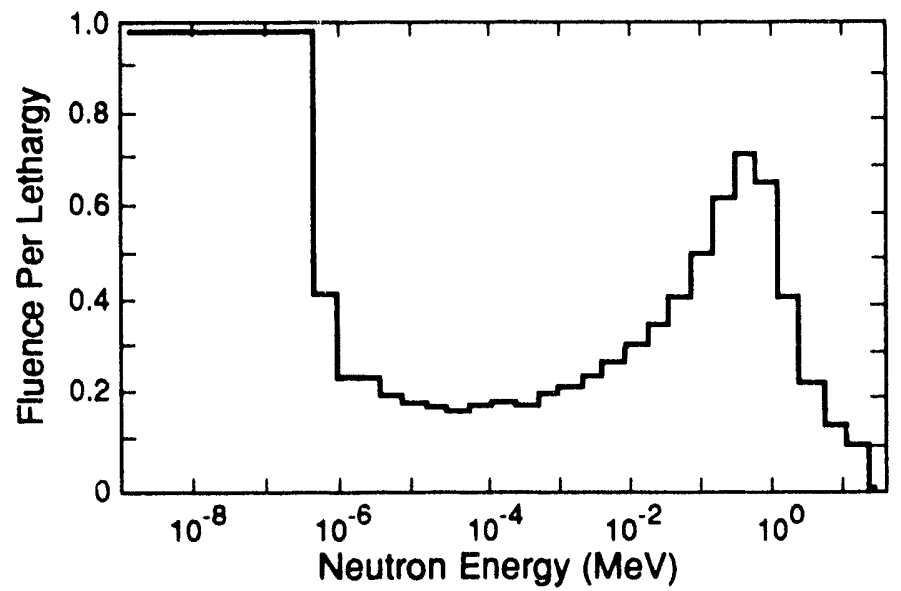

Integral Values

\begin{tabular}{ccc}
\hline Neutron Energy (MeV) & $\phi(\%)$ & $H(\%)$ \\
\hline $7.04 \mathrm{E}-10$ to $4.14 \mathrm{E}-07$ & 60 & 9 \\
$4.14 \mathrm{E}-07$ to $8.41 \mathrm{E}-03$ & 16 & 3 \\
$8.41 \mathrm{E}-03$ to $1.43 \mathrm{E}-01$ & 8 & 6 \\
$1.43 \mathrm{E}-01$ to $1.20 \mathrm{E}+00$ & 11 & 46 \\
$1.20 \mathrm{E}+00$ to $4.94 \mathrm{E}+00$ & 3 & 24 \\
$4.94 \mathrm{E}+00$ to $1.00 \mathrm{E}+01$ & 1 & 6 \\
$1.00 \mathrm{E}+01$ to $2.43 \mathrm{E}+01$ & 1 & 6
\end{tabular}

Figure 16. Neutron spectrum of hallway between rooms 206 and $207(\bar{E}=0.268 \mathrm{MeV} ; \dot{H}=1.09 \mu \mathrm{SV} / \mathrm{h})$.

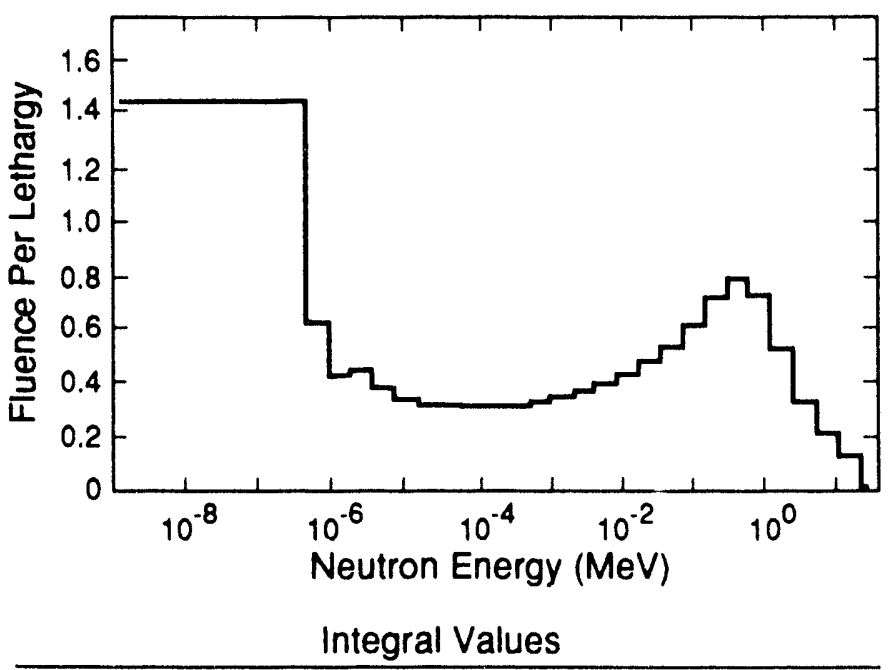

\begin{tabular}{|c|c|c|}
\hline Neutron Energy $(\mathrm{MeV})$ & $\phi(\%)$ & $H(\%)$ \\
\hline $7.04 \mathrm{E}-10$ to $4.14 \mathrm{E}-07$ & 60 & 10 \\
\hline 4.14E-07 to $8.41 \mathrm{E}-03$ & 19 & 5 \\
\hline $8.41 \mathrm{E}-03$ to $1.43 \mathrm{E}-01$ & 8 & 6 \\
\hline $1.43 \mathrm{E}-01$ to $1.20 \mathrm{E}+00$ & 8 & 40 \\
\hline $1.20 E+00$ to $4.94 E+00$ & 3 & 26 \\
\hline $4.94 E+00$ to $1.00 E+01$ & 1 & 7 \\
\hline $1.00 E+01$ to $2.43 E+01$ & 1 & 6 \\
\hline
\end{tabular}

Figure 17. Neutron spectrum of hallway near room 319 $(\bar{E}=0.254 \mathrm{MeV} ; \dot{H}=1.41 \mu \mathrm{Sv} / \mathrm{h})$.

\section{f) Speclal projects glovebox}

To proceed with a facility-wide ALARA assessment, the neutron spectrum emitted from a glovebox, PS, containing a variety of SNMs was measured using the multisphere system. Derived from Figure 18, the measured neutron spectral quantities for this glovebox location result in integral values representing fluence rate, dose equivalent rate, average $Q$, and average neutron energy of $102 \mathrm{n} / \mathrm{cm}^{2} / \mathrm{s}, 35.1 \mu \mathrm{Sv} / \mathrm{h}, 7.30$, and $0.471 \mathrm{MeV}$, respectively.

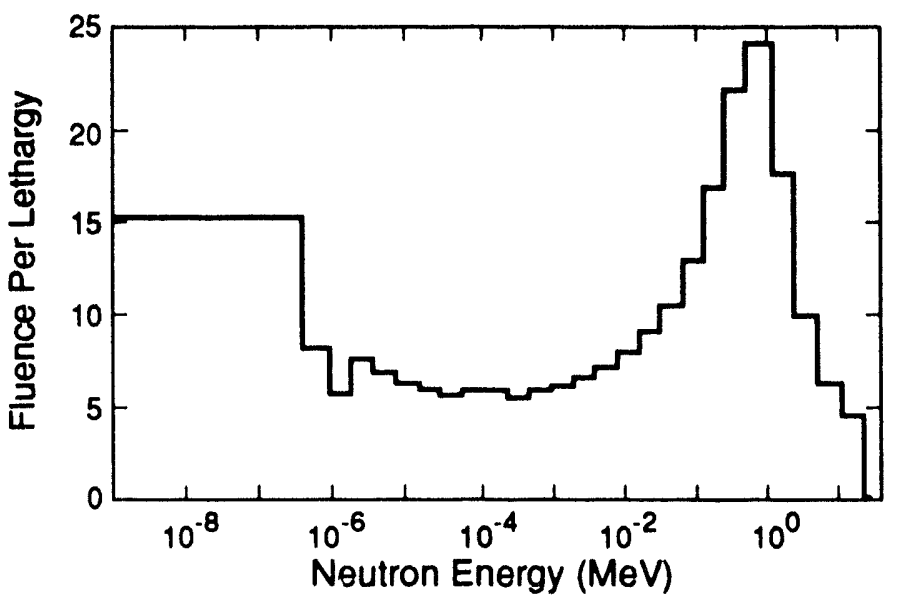

Integral Values

\begin{tabular}{ccc}
\hline Neutron Energy (MeV) & $\phi(\%)$ & $H(\%)$ \\
\hline $7.04 E-10$ to $4.14 \mathrm{E}-07$ & 45 & 4 \\
$4.14 \mathrm{E}-07$ to $8.41 \mathrm{E}-03$ & 21 & 3 \\
$8.41 \mathrm{E}-03$ to $1.43 \mathrm{E}-01$ & 10 & 4 \\
$1.43 \mathrm{E}-01$ to $1.20 \mathrm{E}+00$ & 15 & 45 \\
$1.20 \mathrm{E}+00$ to $4.94 \mathrm{E}+00$ & 7 & 30 \\
$4.94 \mathrm{E}+00$ to $1.00 \mathrm{E}+01$ & 1 & 7 \\
$1.00 \mathrm{E}+01$ to $2.43 \mathrm{E}+01$ & 1 & 7
\end{tabular}

Figure 18. Neutron spectrum of special projects glovebox "PS" $(\bar{E}=0.471 \mathrm{MoV} ; \dot{H}=35.1 \mu \mathrm{Sv} / \mathrm{h}$ ).

\section{Additional measurements}

Photon exposure rates were also measured at each spectral location using a Radcal MDH-1515 instrument coupled to a $180-\mathrm{cm}^{3}$ active volume pancake ionization probe. In addition to these measirements, further neutron field characterizations were acquired by taking ratios of the NRD and $7.62-\mathrm{cm}$ Cd-coated sphere measurements (i.e., "9-10-3 ratios" ${ }^{29.31}$ ) combined with measurements using the NRD ${ }^{10} \mathrm{BF}_{3}$ detector bare and positioned inside a Cd-sleeve. The results of further photon and neutron measurements conducted at the LANL Neutron Well Calibration Facility, the Plutonium Facility, and the low-scatter neutron annex are shown in Table 2. 
Table 2. Site-specific measurements of neutron and photon fields.

\begin{tabular}{|c|c|c|c|c|c|c|}
\hline Location or Source & $\begin{array}{c}\text { 9"-NRD' } \\
\left(8^{-1}\right)\end{array}$ & $\begin{array}{l}\text { 9to-3" } \\
\text { Ratio }\end{array}$ & $\begin{array}{l}\text { Bare } \\
\text { 'BF, } \\
\left(\varepsilon^{-1}\right)\end{array}$ & $\begin{array}{c}\text { Cd-Covered } \\
{ }^{\circ} \mathrm{BF}_{3} \\
\left(\mathbf{s}^{-1}\right)^{3}\end{array}$ & $\begin{array}{l}\text { Thermal } \\
\text { Doseb } \\
(\%)\end{array}$ & $\begin{array}{c}\dot{\mathrm{X}} \\
(\mathrm{mR} / \mathrm{h})\end{array}$ \\
\hline Bare ${ }^{32} \mathrm{CH}$ & 33.00 & $\begin{array}{c}1.99 \\
( \pm 0.006)\end{array}$ & $\begin{array}{r}0.388 \\
( \pm 3.4 \%)\end{array}$ & $\begin{array}{r}0.634 \\
( \pm 1.4 \%)\end{array}$ & $\begin{array}{c}0.79 \\
( \pm 0.10 \%)\end{array}$ & $N M^{4}$ \\
\hline $\begin{array}{l}\text { Simulated Glovebox } \\
4^{4} \text { Lucite }\end{array}$ & 11.1 & $\begin{array}{c}0.683 \\
( \pm 0.95 \%)\end{array}$ & $\begin{array}{l}17.6 \\
( \pm 1.0 \%)\end{array}$ & $( \pm 2.0 \%)$ & $\begin{array}{l}22 \\
( \pm 7.0 \%)\end{array}$ & NM \\
\hline Neutron Well & $\begin{array}{l}31.8 \\
( \pm 1.3 \%)\end{array}$ & $\begin{array}{c}0.741 \\
( \pm 0.75 \%)\end{array}$ & $\begin{array}{c}9.17 \\
( \pm 2.5 \%)\end{array}$ & $\begin{array}{c}1.32 \\
( \pm 6.5 \%)\end{array}$ & 11 & NM \\
\hline Ball Milling & $\begin{array}{l}0.80^{\mathrm{mAA}} \\
( \pm 5.0)\end{array}$ & $\begin{array}{r}0.300 \\
( \pm 3.0 \%)\end{array}$ & $\begin{array}{r}1.7 \mathrm{~mA} \\
( \pm 3.1 \%)\end{array}$ & $\begin{array}{c}0.31^{\text {Mea }} \\
( \pm 12 \%)\end{array}$ & $2.1^{\mathrm{maA}}$ & 1.200 \\
\hline Fired Granules & $\begin{array}{c}0.80 \mathrm{~mA} \\
( \pm 5.0 \%)\end{array}$ & $\begin{array}{c}0.35 \\
( \pm 4.3 \%)\end{array}$ & $\begin{array}{r}1.7 \mathrm{~mA} \\
( \pm 3.1 \%)\end{array}$ & $\begin{array}{c}0.13^{\mathrm{MA}} \\
( \pm 12 \%)\end{array}$ & $2.1 \mathrm{maA}$ & 1.000 \\
\hline $\mathrm{PuO}_{2}$-Sphere (Front) & $\begin{array}{r}0.830 \\
( \pm 4.5 \%)\end{array}$ & $\begin{array}{c}0.30 \\
( \pm 5.1 \%)\end{array}$ & $\begin{array}{c}1.70 \\
( \pm 3.1 \%)\end{array}$ & $\begin{array}{c}0.13 \\
( \pm 12 \%)\end{array}$ & 2.1 & 1.020 \\
\hline $\mathrm{PuO}_{2}$-Sphere (Back) & $\begin{array}{c}1.72 \\
( \pm 3.1 \%)\end{array}$ & $\begin{array}{c}0.38 \\
( \pm 3.6 \%)\end{array}$ & $\begin{array}{c}3.20 \\
( \pm 2.3 \%)\end{array}$ & $\begin{array}{c}0.23 \\
( \pm 12 \%)\end{array}$ & 4.0 & 1.430 \\
\hline HF & $\begin{array}{r}0.785 \\
( \pm 4.6 \%)\end{array}$ & $\begin{array}{c}0.32 \\
( \pm 4.6 \%)\end{array}$ & $\begin{array}{c}2.08 \\
( \pm 2.8 \%)\end{array}$ & $\begin{array}{r}0.80 \\
( \pm 14 \%)\end{array}$ & 2.6 & 0.359 \\
\hline Precipitation & $\begin{array}{c}1.27 \\
( \pm 3.6 \%)\end{array}$ & $\begin{array}{c}0.65 \\
( \pm 4.6 \%)\end{array}$ & $\begin{array}{r}0.048 \\
( \pm 18 \%)\end{array}$ & $\begin{array}{r}0.028 \\
( \pm 24 \%)\end{array}$ & 0.060 & 0.884 \\
\hline Eveporation & $\begin{array}{r}0.213 \\
( \pm 8.8 \%)\end{array}$ & $\begin{array}{c}0.38 \\
( \pm 10 \%)\end{array}$ & $\begin{array}{c}0.13 \\
( \pm 11 \%)\end{array}$ & $\begin{array}{r}0.23 \\
( \pm 17 \%)\end{array}$ & 0.16 & 0.936 \\
\hline Vault $\mathrm{K}$ & $\begin{array}{c}4.00 \\
( \pm 6.4 \%)\end{array}$ & $\begin{array}{c}0.24 \\
( \pm 7.2 \%)\end{array}$ & $\begin{array}{c}13.2 \\
( \pm 3.6 \%)\end{array}$ & $\begin{array}{c}0.78 \\
( \pm 15 \%)\end{array}$ & 17 & 8.000 \\
\hline Vault D & $\begin{array}{c}7.03 \\
( \pm 4.9 \%)\end{array}$ & $\begin{array}{c}0.26 \\
( \pm 5.4 \%)\end{array}$ & $\begin{array}{c}22.8 \\
( \pm 1.7 \%)\end{array}$ & $\begin{array}{c}1.4 \\
( \pm 11 \%)\end{array}$ & 28 & 2.200 \\
\hline Glovebox PS & $\begin{array}{c}2.00 \\
( \pm 4.1 \%)\end{array}$ & $\begin{array}{c}0.22 \\
( \pm 4.5 \%)\end{array}$ & $\begin{array}{c}5.0 \\
( \pm 2.6 \%)\end{array}$ & $\begin{array}{c}0.13 \\
( \pm 9.4 \%)\end{array}$ & 6.2 & 1.227 \\
\hline Hall by 206 & $\begin{array}{r}0.079 \\
( \pm 8.4 \%)\end{array}$ & $\begin{array}{c}0.22 \\
( \pm 9.2 \%)\end{array}$ & $\begin{array}{c}3.73 \\
( \pm 3.8 \%)\end{array}$ & $\begin{array}{r}0.18 \\
( \pm 18 \%)\end{array}$ & 4.7 & 0.060 \\
\hline Hall by 319 & $\begin{array}{r}0.236 \\
( \pm 8.4 \%)\end{array}$ & $\begin{array}{c}0.15 \\
( \pm 9.0 \%)\end{array}$ & $\begin{array}{c}1.53 \\
( \pm 3.3 \%)\end{array}$ & $\begin{array}{r}0.088 \\
( \pm 14 \%)\end{array}$ & 1.9 & 0.422 \\
\hline
\end{tabular}

a. Response of the Eberline 22.8 (9-inch) NRD is 38 counts $/\left(0.01^{*} \mathrm{mSv}\right) / \mathrm{h}$.

b. Percent thermal by dose is estimated using the following method (personal communication and consulting with Dale Hankins): Percent thermal by dose $=$ Bare ${ }^{10} \mathrm{BF}$, Response/80, where the value of 80 is to corr $u c t$ the overresponse of the ${ }^{10} \mathrm{BF}$, probe to epithermal and thermal neutrons relative to fission sources (e.g., the average ${ }^{10} \mathrm{BF}_{3}$ detector response for a thermal pile divided by its average response for fission sources).

c. Measured performance at a source-to-detector distance of $100 \mathrm{~cm}$.

d. MLA = measurements performed in local area; $N M=$ not measured. 


\section{Calculated dosimeter/remmeter response values}

The 27 TWOGO energy group midpoint values, differential energy values, and interpolated NCRP 38 and ICRP 60 fluenceto-dose-equivalent conversion factors are shown in Table 3 . The corresponding response values for bare and albedo ${ }^{\circ} \mathrm{LiF}$ TL.Ds, BDI-100 bubble detectors, CR-39, NTA film, NRD, and Snoopy monitors are shown in Table 4. These values were folded with each measured neutron spectrum to determine the dosimeter or remmeter responses per unit-dose equivalent. The spectralweighted dosimeter and remmeter response values are shown in Table 5. The best-performing dosimeters for use in the Plutonium Facility were determined and ranked strictly on a calculational basis without the application of neutron correction factors and without regard for operational concerns. Overall, bubble detectors ranked best in facility response with CR-39, NTA, albedo ${ }^{6} \mathrm{LiF}$ TLDs, and bare ${ }^{6} \mathrm{LiF}$ TLDs following in descending order. The standard deviation of the calculated response values determined for the Snoopy remmeter was 5.0\% better than the NRD for the spectra measured at this facility. However, when the weight and directional response variations of the Snoopy remmeter ( $11.3 \mathrm{~kg} ; \pm 20$ to $30 \%)$ are compared to th.i weight and angular variations of the NRD $(6.24 \mathrm{~kg} ; \pm 10 \%)$, operational, facility, and budget priorities should dominate in the decision of which instrument to utilize.
Table 3. TWOGOs differential energy values, neutron energies, NCRP 38 and ICRP 60 fluence-to-dose-equivalent values.

\begin{tabular}{|c|c|c|c|}
\hline Noutron Energy & $\begin{array}{c}\text { TWOGO } \\
\text { Difforential } \\
\text { Energy Values } \\
(\mathrm{MeV})\end{array}$ & $\begin{array}{l}\text { NCRP } 38 \\
\text { Fluence-to- } \\
\text { Dose } \\
\text { Equivalent } \\
\left(0.01^{\circ} \text { mSv"cm }^{2}\right)\end{array}$ & $\begin{array}{c}\text { ICRP 60 } \\
\text { Fluence-10- } \\
\text { Dose } \\
\text { Equlvalent } \\
\left(0.01 \text { ' }^{\prime} \mathrm{msv}^{\circ} \mathrm{cm}^{2}\right)\end{array}$ \\
\hline $2.540^{\circ} 10^{\circ}$ & $4.140^{*} 10^{7}$ & $1.021^{\circ} 10^{\circ}$ & $1.201^{\circ} 10^{\circ}$ \\
\hline $5.900^{\circ} 10^{\prime}$ & $4.270^{\circ} 10^{7}$ & $1.090^{\circ} 10^{\circ}$ & $1.485^{\circ} 10^{\circ}$ \\
\hline $1.200^{\circ} 10^{\circ}$ & $8.690^{\circ} 10^{\prime}$ & $1.240^{\circ} 10^{\circ}$ & $1.548^{\circ} 10^{\circ}$ \\
\hline $2.440^{\circ} 10^{\circ}$ & $1.760^{\circ} 10^{\circ}$ & $1.240^{\circ} 10^{\circ}$ & $1.533^{\circ} 10^{\circ}$ \\
\hline $4.940^{\circ} 10^{\circ}$ & $3.570^{\circ} 10^{\circ}$ & $1.240^{\circ} 10^{\circ}$ & $1.504^{\circ} 10^{\circ}$ \\
\hline $1.000^{*} 10^{5}$ & $7.260^{\circ} 10^{\circ}$ & $1.240^{\circ} 10^{\circ}$ & $1.450^{\circ} 10^{\circ}$ \\
\hline $2.040^{*} 10^{5}$ & $1.480^{*} 10^{5}$ & $1.239^{\circ} 10^{\circ}$ & $1.424^{\circ} 10^{6}$ \\
\hline $4.140^{*} 10^{5}$ & $2.990^{\circ} 10^{\mathrm{s}}$ & $1.234^{\circ} 10^{\circ}$ & $1.373^{*} 10^{\circ}$ \\
\hline $8.410^{\circ} 10^{5}$ & $6.110^{*} 10^{5}$ & $1.210^{\circ} 10^{\circ}$ & $1.281^{\circ} 10^{6}$ \\
\hline $1.710^{\circ} 10^{4}$ & $1.230^{\circ} 10^{4}$ & $1.182^{*} 10^{\circ}$ & $1.226^{*} 10^{\circ}$ \\
\hline $3.460^{*} 10^{4}$ & $2.510^{\circ} 10^{4}$ & $1146^{\circ} 10^{\circ}$ & $1.178^{\circ} 10^{\circ}$ \\
\hline $7.030^{*} 10^{4}$ & $5.060^{\circ} 10^{4}$ & $1.076^{\circ} 10^{\circ}$ & $1.150^{\circ} 10^{\circ}$ \\
\hline $1.430^{*} 10^{3}$ & $1.040^{*} 10^{3}$ & $9.480^{\circ} 10^{7}$ & $1.163^{*} 10^{6}$ \\
\hline $2.910^{\circ} 10^{3}$ & $2.100^{*} 10^{3}$ & $7.518^{*} 10^{7}$ & $1.232^{\circ} 10^{\circ}$ \\
\hline $5.900^{\circ} 10^{3}$ & $4.270^{\circ} 10^{3}$ & $6.149^{\circ} 10^{\prime}$ & $1.441^{\circ} 10^{\circ}$ \\
\hline $1.200^{*} 10^{2}$ & $8.690^{\circ} 10^{3}$ & $1.106^{\circ} 10^{\circ}$ & $1.945^{\circ} 10^{\circ}$ \\
\hline $2.440^{\circ} 10^{2}$ & $1.760^{*} 10^{2}$ & $1.814^{\circ} 10^{\circ}$ & $3.159^{\circ} 10^{\circ}$ \\
\hline $4.940^{*} 10^{2}$ & $3.570^{\circ} 10^{2}$ & $3.229^{\circ} 10^{\circ}$ & $5.829^{\circ} 10^{\circ}$ \\
\hline $1.000^{*} 10^{\prime}$ & $7.260^{*} 10^{2}$ & $6.039^{*} 10^{\circ}$ & $1.123^{\circ} 10^{5}$ \\
\hline $2.040^{\circ} 10^{\prime}$ & $1.480^{*} 10^{\prime}$ & $1.158^{*} 10^{5}$ & $2.133^{\circ} 10^{5}$ \\
\hline $4.140^{\circ} 10^{\prime}$ & $2.990^{\circ} 10^{\prime}$ & $2.186^{*} 10^{5}$ & $3.6311^{*} 10^{.6}$ \\
\hline $8.410^{\circ} 10^{\prime}$ & $6.100^{*} 10^{1}$ & $3.372 * 10^{-6}$ & $5.386^{\circ} 10^{6}$ \\
\hline $1.710^{*} 10^{\circ}$ & $1.230^{*} 10^{\circ}$ & $4.210^{*} 10^{6}$ & $6.684^{*} 10^{.6}$ \\
\hline $3.460^{\circ} 10^{\circ}$ & $2.510^{\circ} 10^{\circ}$ & $3.961^{\circ} 10^{5}$ & $6.948^{\circ} 10^{6}$ \\
\hline $7.030^{\circ} 10^{\circ}$ & $5.060^{\circ} 10^{\circ}$ & $4.074^{\circ} 10^{6}$ & $6.405^{\circ} 10^{6}$ \\
\hline $1.430^{\circ} 10^{\prime}$ & $1.040^{\circ} 10^{\prime}$ & $5.822^{*} 10^{5}$ & $5.573^{\circ} 10^{\circ}$ \\
\hline $2.230 * 10^{\prime}$ & $3.935^{\circ} 10^{\circ}$ & $6.421^{\circ} 10^{B}$ & $5.200^{*} 10^{6}$ \\
\hline
\end{tabular}


Table 4. Relative and absolute dosimeter/remmeter response values calculated for the 27 energy groups of TWOGO.

\begin{tabular}{|c|c|c|c|c|c|c|}
\hline $\begin{array}{c}\text { Bare } \\
\text { UTLD } \\
\text { (Relative } \\
\text { Reeponee) }\end{array}$ & $\begin{array}{c}\text { Albedo } \\
\text { UT TLD } \\
\text { (Relative } \\
\text { Reoponse) }\end{array}$ & $\begin{array}{l}\text { BDI-100 } \\
\text { (Bubbles } \\
\text { per } \mathrm{cm}^{2} \text { ) }\end{array}$ & $\begin{array}{c}\text { CR-39 } \\
\text { (Tracks } \\
\text { per Neutron) }\end{array}$ & $\begin{array}{c}\text { NTA } \\
\text { (Tracke } \\
\text { per Neutron) }\end{array}$ & $\begin{array}{l}9^{\prime \prime} \text {-NRD } \\
\text { (Counts } \\
\text { per omn) }\end{array}$ & $\begin{array}{l}\text { Snoopy } \\
\text { (Counts } \\
\text { por } \mathrm{cm}^{2} \text { ) }\end{array}$ \\
\hline $7.400 * 10^{-1}$ & $6.680^{\circ} 10^{\circ}$ & 0 & 0 & 0 & $3.700^{*} 10^{3}$ & $5.370^{\circ} 10^{3}$ \\
\hline $5.696^{\circ} 10^{-1}$ & $9.961 \cdot 10^{3}$ & 0 & 0 & 0 & $6.170^{\circ} 10^{3}$ & $8.825^{\circ} 10^{3}$ \\
\hline $5.358 * 10^{\prime}$ & $3.076^{\circ} 10^{2}$ & 0 & 0 & 0 & $6.700^{*} 10^{3}$ & $9.957^{*} 10^{-3}$ \\
\hline $4.999 \cdot 10^{-1}$ & $1.038^{\circ} 10^{\prime}$ & 0 & 0 & 0 & $7.760^{*} 10^{3}$ & $1.127^{*} 10^{2}$ \\
\hline $4.699^{*} 10^{\prime}$ & $9.665^{\circ} 10^{2}$ & 0 & 0 & 0 & $8.720^{\circ} 10^{\mathrm{J}}$ & $1.281 \cdot 10^{2}$ \\
\hline $4.390^{\circ} 10^{\prime}$ & $8.800^{*} 10^{2}$ & 0 & 0 & 0 & $8.720^{\circ} 10^{\mathrm{J}}$ & $1.450^{*} 10^{2}$ \\
\hline $4.078 * 10^{\prime}$ & $7.584^{*} 10^{2}$ & 0 & 0 & 0 & $9.810^{\circ} 10^{3}$ & $1.642^{*} 10^{2}$ \\
\hline $3.787^{\circ} 10^{\prime}$ & $6.571 \cdot 10^{2}$ & 0 & 0 & 0 & $1.100^{*} 10^{2}$ & $i .875^{\circ} 10^{2}$ \\
\hline $3.563^{*} 10^{\prime}$ & $5.530^{*} 10^{2}$ & 0 & 0 & 0 & $1.240^{*} 10^{2}$ & $2.105^{*} 10^{2}$ \\
\hline $3.265^{\circ} 10^{\prime}$ & $4.726^{*} 10^{2}$ & 0 & 0 & 0 & $1.390^{\circ} 10^{2}$ & $2.423^{\circ} 10^{2}$ \\
\hline $3.067 \times 10^{\prime}$ & $4.350^{*} 10^{2}$ & 0 & 0 & 0 & $1.570^{\circ} 10^{2}$ & $2.702^{*} 10^{2}$ \\
\hline $2.808^{\circ} 10^{\prime}$ & $4.120^{*} 10^{2}$ & 0 & 0 & 0 & $1.760^{*} 10^{2}$ & $3.106^{\circ} 10^{2}$ \\
\hline $2.656^{\circ} 10^{\prime}$ & $3.630^{*} 10^{2}$ & 0 & 0 & 0 & $1.980^{\circ} 10^{2}$ & $3.474^{*} 10^{2}$ \\
\hline $2.448^{*} \cdot 10^{\prime}$ & $3.737^{*} 10^{2}$ & 0 & 0 & 0 & $2.220^{*} 10^{2}$ & $4.007^{\circ} 10^{2}$ \\
\hline $2.332^{*} 10^{\prime}$ & $2.759^{*} 10^{2}$ & 0 & 0 & 0 & $2.480^{\circ} 10^{\circ}$ & $4.484^{\circ} 10^{2}$ \\
\hline $2.146^{\circ} 10^{\prime}$ & $2.508^{\prime} 10^{2}$ & 0 & 0 & 0 & $2.670^{\circ} 10^{2}$ & $5.494^{\circ} 10^{2}$ \\
\hline $2.025^{*} 10^{\prime}$ & $2.252^{*} 10^{2}$ & 0 & 0 & 0 & $2.950^{*} 10^{2}$ & $6.443^{\prime} 10^{2}$ \\
\hline $1.912^{\circ} 10^{\prime}$ & $1.956^{*} 10^{2}$ & 0 & 0 & 0 & $3.230^{\circ} 10^{2}$ & $7.398^{*} 10^{2}$ \\
\hline $1.800^{*} 10^{\prime}$ & $1.700^{*} 10^{2}$ & $1.000^{\circ} 10^{\circ}$ & $4.860^{\circ} 10^{\circ}$ & 0 & $3.770^{\circ} 10^{2}$ & $9.260^{*} 10^{2}$ \\
\hline $1.634^{*} 10^{\prime}$ & $1.494^{\circ} 10^{2}$ & $6.628^{\circ} 10^{6}$ & $6.524^{\circ} 10^{\mathrm{s}}$ & 0 & $4.840^{\circ} 10^{2}$ & $1.346^{\circ} 10^{\prime}$ \\
\hline $1.448^{\circ} 10^{\prime}$ & $1.261^{\circ} 10^{2}$ & $2.302 * 10^{\mathrm{s}}$ & $1.353^{\circ} 10^{\circ}$ & $1.732^{*} 10^{\circ}$ & $6.990^{\circ} 10^{2}$ & $2.124^{\circ} 10^{\prime}$ \\
\hline $1.237^{\circ} 10^{\prime}$ & $9.256^{*} 10^{3}$ & $2.268^{\circ} 10^{5}$ & $1.930 * 10^{4}$ & $2.410^{*} 10^{4}$ & $9.080^{*} 10^{2}$ & $3.601^{\circ} 10^{\prime}$ \\
\hline $9.786^{\circ} 10^{2}$ & $5.780^{\circ} 10^{3}$ & $2.548^{\circ} 10^{\mathrm{s}}$ & $2.767^{\circ} 10^{4}$ & $3.872 * 10^{4}$ & $1.050^{\circ} 10^{\prime}$ & $4.579 * 10^{\prime}$ \\
\hline $7.015^{\prime} 10^{2}$ & $4.047^{*} 10^{3}$ & $2.802^{\circ} 10^{\mathrm{s}}$ & $2.367^{\circ} 10^{4}$ & $5.585^{\circ} 10^{4}$ & $1.010^{\circ} 10^{\prime}$ & $4.519 * 10^{\prime}$ \\
\hline $4.576^{\circ} 10^{2}$ & $2.632^{*} 10^{3}$ & $3.329 \cdot 10^{\mathrm{s}}$ & $1.775^{\circ} 10^{4}$ & $8.444^{\circ} 10^{4}$ & $9250^{\circ} 10^{2}$ & $4.284^{*} 10^{\prime}$ \\
\hline $2.946^{*} 10^{2}$ & $1.561^{\cdot} 10^{3}$ & $2.945^{\circ} 10^{\mathrm{s}}$ & $1.510^{*} 10^{4}$ & $6.736^{*} 10^{4}$ & $6.720^{*} 10^{2}$ & $3.012^{*} 10^{\prime}$ \\
\hline $2.230^{*} 10^{2}$ & $1.080^{\circ} 10^{3}$ & $1.500^{\circ} 10^{\mathrm{s}}$ & $5.465^{\circ} 10^{s}$ & $4.278 * 10^{4}$ & 0 & $2.211^{\circ} 10^{\prime}$ \\
\hline
\end{tabular}


Table 5. Spectrum-weighted remmeter and dosimeter $\bar{R}_{d}$ response values.

\begin{tabular}{|c|c|c|c|c|c|c|c|c|}
\hline Spectrum & $\begin{array}{c}f \\
\left(10^{-1 *} \mathrm{msv}\right. \\
\mathrm{cm} \text { " })\end{array}$ & $\begin{array}{c}9 " \\
\text { NRD } \\
\text { (count per } \\
0.01^{\circ} \mu \mathrm{Sv} \text { ) }\end{array}$ & $\begin{array}{l}\text { Snoopy } \\
\text { (count per } \\
0.011^{\prime} \mu \mathrm{Sv} \text { ) }\end{array}$ & $\begin{array}{c}\text { BDH-100 } \\
\text { (bubbles per } \\
0.01 \text { * } \mu 9 v \text { ) }\end{array}$ & $\begin{array}{c}\text { CR-39 } \\
\text { (trecke per } \\
0.011^{*} \mu \mathrm{SV} \text { ) }\end{array}$ & $\begin{array}{c}\text { NTA } \\
\text { (tracke per } \\
0.01^{*} \mu \mathrm{Sv} \text { ) }\end{array}$ & $\begin{array}{c}\text { Bare } \\
\text { TLD } \\
\text { Rel Reap }\end{array}$ & $\begin{array}{l}\text { Albedo } \\
\text { TLD } \\
\text { Rel Reep }\end{array}$ \\
\hline Bare ${ }^{2} \mathrm{Cl}$ & 3.590 & 2535 & 10870 & 1.000 & 5.945 & 10.59 & 2806 & 196.8 \\
\hline 4"L-D-P" & 1.075 & 2321 & 9586 & 0.8914 & 4.605 & 10.27 & 46330 & 808.9 \\
\hline $4^{\prime \prime L-P-D "}$ & 1.602 & 2405 & 10090 & 0.9490 & 5.048 & 10.51 & 24390 & 614.3 \\
\hline Neutron Well & 2.324 & 2394 & 10290 & 0.9741 & 5.172 & 11.51 & 10390 & 572.4 \\
\hline Fired Granules & 0.9764 & 2736 & 10470 & 0.9228 & 5.103 & 7.650 & 51880 & 1225 \\
\hline $\begin{array}{l}\text { Ball Milling } \\
\text { zupuO, Sphere }\end{array}$ & 0.9769 & 2704 & 10420 & 0.9287 & 5.101 & 7.738 & 48930 & 1075 \\
\hline $\begin{array}{c}\text { (Front) } \\
\text { sopuO }\end{array}$ & 0.9764 & 2675 & 10360 & 0.9268 & 5.132 & 7.868 & 50060 & 1081 \\
\hline (Back) & 1.247 & 2694 & 10550 & 0.9531 & 5.276 & 8.005 & 32970 & 984.5 \\
\hline Vault K & 0.6919 & 2990 & 10780 & 0.8863 & 4.880 & 6.704 & 72160 & 2048 \\
\hline Vault D & 0.8070 & 2967 & 10840 & 0.9108 & 5.023 & 6.813 & 57540 & 1926 \\
\hline HF` & 0.7400 & 2914 & 10680 & 0.8989 & 4.926 & 6.820 & 67550 & 1646 \\
\hline Precips & 2.210 & 2538 & 10410 & 0.9783 & 5.394 & 9.007 & 10180 & 625.8 \\
\hline Evap" & 1.957 & 2595 & 10510 & 0.9780 & 5.411 & 8.762 & 13520 & 730.6 \\
\hline BoxPS & 0.8528 & 2898 & 10730 & 0.9129 & 5.032 & 7.248 & 54160 & 1828 \\
\hline Hall;:206 & 0.5513 & 3035 & 10660 & 0.8490 & 4.604 & 6.114 & 98290 & 2071 \\
\hline Hall;319 & 0.4886 & 3089 & 10660 & 0.8148 & 4.416 & 6.459 & 113200 & 2599 \\
\hline $\begin{array}{c}\text { Averages Pu } \\
\text { Facility }(n=12)\end{array}$ & 1.0 & 2800 & 10600 & 0.91 & 5.02 & 7.4 & 56000 & 1500 \\
\hline \pm SEM & 0.15 & 53 & 45 & 0.014 & 0.085 & 0.26 & 8700 & 180 \\
\hline $\pm \%$ SEM & 15 & 1.9 & 0.43 & 1.5 & 1.7 & 3.5 & 16 & 12 \\
\hline
\end{tabular}

a. L-D.P = Lucite-Detector - Phantom; L-P-D $=$ Lucite - Phantom Detector; HF $=$ Hydrofluorination; Precip = Precipitation; Evap = Evaporation; Average Plutonium Facility values from rows 5 through 16. 


\section{ICRP 60 Impllcations}

In the limit of infinitesimally thin tissue volume, the $w_{R}$ factor approximates a point in space. Under these conditions, the ratio of $\bar{w}_{\mathrm{z}} / \overline{\mathrm{Q}}$ is valid for a given spectrum, and the folded results for these measurements are shown in Table 6. Average quotients determined for site- and facility-specific areas are also shown in this table for reference. Applying equations 3 and 4 to the 12 neutron spectra measured in the Plutonium Facility results in an estimated increased risk (i.e., somatic cell cancer risk per unitdose equivalent) that is $2.32 \pm 0.064( \pm 2.7 \%$ ) times greater than is currenuly calculated using accepted DOE methods (i.e., Order 5480.11 ) that are based on NCRP 38 fluence-to-dose conversion factors. If one weights these measurements according to use factors and dose-equivalent rates, then it becomes apparent that the hallways present a negligible component to the total risk for workers who rou. 'nely work near glovebox operations. Neglecting the hall measurements reduces the estimated risk to $2.25 \pm$ $0.054( \pm 2.4 \%)$. To effectively implement the recommendations of ICRP 60 would require a reduction of the maximum annual dose equivalent presently allowed by the DOE by at least a factor of two.
Table 6. A comparison of $\bar{w}_{A}$ and $\bar{Q}$ values calculated for an infinitesimally thin slice of tissue.

\begin{tabular}{|c|c|c|c|}
\hline Spectrum" & $\overline{w_{n}}$ & $\bar{a}$ & $\bar{w}_{n} / \bar{Q}$ \\
\hline Bare ${ }^{20} \mathrm{Cl}$ & 17.1 & 9.23 & 1.86 \\
\hline $4^{\prime \prime L}-D-P^{\circ}$ & 14.7 & 7.21 & 2.04 \\
\hline $4^{\prime \prime L}-P \cdot D^{\circ}$ & 15.6 & 7.91 & 1.96 \\
\hline Neutron Well & 15.2 & 8.17 & 1.86 \\
\hline Fired Granules & 17.1 & 7.52 & 2.28 \\
\hline Ball Milling & 17.1 & 7.61 & 2.25 \\
\hline $\begin{array}{c}{ }^{2 s} \mathrm{PuO}_{2} \text {-Sphere } \\
\text { (Front) }\end{array}$ & 17.1 & 7.60 & 2.25 \\
\hline $\begin{array}{c}\text { 2upuO } \mathrm{O}_{2} \text {-Sphere } \\
\text { (Back) }\end{array}$ & 17.4 & 8.07 & 2.15 \\
\hline Vault K & 17.0 & 6.87 & 2.48 \\
\hline Vault D & 17.3 & 7.24 & 2.40 \\
\hline Hydrofluorination & 17.1 & 7.06 & 2.42 \\
\hline Precipitation & 17.2 & 8.76 & 1.97 \\
\hline Evaporation & 17.3 & 8.65 & 2.00 \\
\hline Glovebox "PS" & 17.2 & 7.30 & 2.34 \\
\hline Hall by 206 & 16.7 & 6.34 & 2.63 \\
\hline Hall by 319 & 16.0 & 5.92 & 2.70 \\
\hline
\end{tabular}

a. Average values for $\bar{w}_{\mathbb{R}} \sqrt{\mathrm{Q}} \pm$ SEM for site-specific areas within the Plutonium Facility:

$\begin{array}{lll}\text { Plutonium Facility: } & (n=12) & 2.32 \pm 0.064( \pm 2.7 \%) \\ \text { Area 200, rows } 5 \text { through } 8: & (n=4) & 2.23 \pm 0.028( \pm 1.2 \%) \\ \text { Vault areas K and D: } & (n=2) & 2.44 \pm 0.042( \pm 1.7 \%) \\ \text { Precip/Evap, rows } 12 \text { through 13: } & (n=2) & 1.98 \pm 0.017( \pm 0.86 \%) \\ \text { Hall areas: } & (n=2) & 2.66 \pm 0.035( \pm 1.3 \%)\end{array}$

b. L-D-P = Lucite-Detector-Phantom; L.P.D = Lucite-Phantom. Detector 


\section{DISCUSSION}

The LANL Plutonium Facility is neutron abundant. This facility's massive containment is composed of concrete, Lucite, water, and steel and results in multiple neutron scattering, thereby simulating a semi-infinite domain of moderation. Eventually, an equilibrium is established between neutron absorption following moderation and the creation of neutrons from new fission events. This equilibrium produces neutrons having an average energy of $260 \mathrm{keV} \pm 2.6 \%$ (average values \pm SEM) as was measured with the multisphere system in two hall corridors at opposing ends of this facility.

Neutron energies ranging from thermal to $0.41 \mathrm{cV}$ account for $45 \% \pm 4.62 \%$ (average $\pm S E M$ ) of the total fluences measured in the Plutonium Facility. Folding in NCRP 38 fluence-to-doseequivalent conversions factors for these spectral fluences reveals that these thermal and epithermal neutrons contribute only $4.5 \%$ $\pm 0.84 \%$ (average \pm SEM) of the total measured dose equivalent for the 12 Plutonium Facility locations measured. The personnel neutron dosimeters currently used at LANL utilize bare ' $\mathrm{LiF} /$ ' $\mathrm{LiF}$ pairs, and $(n, \alpha)$ reaction cross sections for these detectors are maximum at thermal energies. Dosimeters based on this concept are extremely sensitive to small changes in moderation. Material processing may also result in dynamic neutron energies, further changing thermal and epithermal components and demanding dynamic neutron correction factors to adjust TLD responses to the correct dose equivalent. Perhaps the most vulnerable aspect of the LANL TLD system is that it is sensitive to small changes in thermal/epithermal energies, at which these neutrons contribute a very small component to the dose equivalent. For such spectra, bubble detectors and CR-39 do not depend on neutron correction factors and are calculated to be more accurate for personnel neutron dosimetry use throughout the Plutonium Facility.

Application of ICRP 38 fluence-to-dose-equivalent conversion factors to all measured neutron energies for each of the laboratory access corridor areas results in a calculated (average $\pm S E M$ ) neutron-dose equivalent rate of $1.25 \pm 0.160$ $(12.8 \%) \mu \mathrm{Sv} / \mathrm{h}$. The average ( $\pm \mathrm{SEM}$ ) dose-equivalent rate measured for photons in these hallways was $2.10 \pm 1.81(86.2 \%)$ $\mu \mathrm{S} v \mathrm{~h}$. When combined, neutrons and photons account for hallway dose-equivalent rates of $2.63 \pm 1.82 \mu \mathrm{Sv} / \mathrm{h}$. This rate results in maximum monthly ( $8 \mathrm{~h} / \mathrm{day}$ * 5 days/weck * 4 wecks/ month) and annual absorbed dose-equivalents of $420 \pm 290 \mu \mathrm{Sv}$ and $5500 \pm 3800 \mu \mathrm{Sv}$, respectively.

Currently our monthly, whole-body TLD badge cutoff value, determined for statistical reasons pertaining to eliminating false positive reporting, is set at $100 \mu \mathrm{Sv} /$ month. It is conceivable that individuals who spend an average of only $4 \mathrm{~h} /$ day in the Plutonium Facility hallways without entering other controlled areas in this facility would, using NCRP 38 fluence-to-dose-equivalent conversions, receive approximately $1000 \mu \mathrm{Sv} /$ year above background. Because of current policy, a zero-dose cquivalent is entered into record for dose equivalents measured below the cutoff value. It is therefore possible, although unlikely, for employees to receive $1000 \mu \mathrm{Sv} /$ year but be reported as not recciving any occupational dose-equivalent exposure. For reference, the annual whole-body absorbed-dose equivalent that is due to natural background radiation in the Los Alamos area is $3400 \mu \mathrm{Sv}$.

Significant differences in neutron spectra werc measured for anterior versus posterior irradiations. These differences are summarized for each remmeter and dosimeter investigated in this report and are shown in Table 7. These results clearly show that the NRD, Snoopy, BDI-100 bubble detectors, CR-39, and NTA film are calculated to respond within $10 \%$ for anterior versus posterior irradiations. Both the bare and albedo ${ }^{\circ} \mathrm{LiF}$ TLDs, being much more sensitive to changes in small components of thermal and epithermal neutrons, significantly underrespond for posterior versus anterior irradiations (32\% for albedo TLDs and $90 \%$ for bare TLDs). These differences reveal the complexity of personnel neutron dosimetry for highly moderated spectra and the inadequacy of assigning one personnel neutron correction factor to a TLD dosimeter for only one specific static glovebox operation. These results combined with earlier investigations' suggest ways to improve the accuracy of neutron measurements by using a dosimeter system that does not rely on changing neutron correction factors. Such a dosimeter system could employ a TLD algorithm that selectively incorporates an average neutron correction factor representative of the average neutron energies encountered in field environments. ${ }^{32}$ In addition, other types of TLD dosimeters combined with either bubble detectors ${ }^{33-35}$ or CR-396 would help refine personnel neutron measurements at LANL. These measurements are directly relevant to the recently published ANSI/ANS-6.1.11991.," which deals with neutron and gamma- ray fluence-todose factors regarding anterior, posterior, lateral, and rotational exposure geometries.

Table 7. Percent differences calculated for anterior versus posterior ${ }^{252} \mathrm{Ct}$ source irradiations through a $10.2-\mathrm{cm}$ Lucite shield.

\begin{tabular}{|cc|}
\hline Remmetor or Dosimater & $\begin{array}{c}\text { Anterlor Vereus Postorlor } \\
\text { Difference }(\%)^{*}\end{array}$ \\
\hline $90^{\circ}$ NRD & +3.49 \\
Snoopy & +5.00 \\
BDI-100 & +6.07 \\
CR-39 & +8.78 \\
NTA & +2.28 \\
Bare TLD & -90.0 \\
Albedo TLD & -31.7 \\
\hline
\end{tabular}

a. Positive (+) values represent an increased variation for posterior irradiation when compared to anterior irradiations. Likewise, negative (.) values reflect a decreased response calculated for posterior versus anterior irradiations. Values were calculated from Table 5; 4"L.D.P and 4"L.P.D rows. 
These measurements were performed over a three week period: with regard to ALARA considerations, they resulted in dose equivalents, measured with the current LANL TLD dosimeter, of $420 \pm 75$ person- $\mu S v$ shallow penetrating photon dose and $1650 \pm 138$ person- $\mu S v$ neutron dose. These measurements have resulted in significantly reduced personnel neutrondose equivalents imparted at site-specific locations and will provide the foundations for future policy regarding dosimetry practices performed at this facility.

The response function interpolation code used to calculate these results is written in Turbo Basic ${ }^{3}$ format while the dosimeter, remmeter, and folding parameters, compatible for TWOGOs 27 energy groups, are written in spread sheet format." The latter code accepts neutron flux values folded by TWOGO to calculate dosimeter/remmeter response values for a given spectra. All programs are available upon request pending the consent of LANL and the DOE.

\section{ACKNOWLEDGMENTS}

The administrative support of r.r. Richard Brake for arranging this collaboration is gratefully acknowledged. We thank Liz Foltyn and Roy Zocher of Nuclear Materials Technology for their pursuit of ALARA goals in helping us to initiale our measurements throughout the LANL ${ }^{230} \mathrm{Pu}$ operations and in providing careful reviews of this work. Sincere thanks are extended to Leonard Romero and Jeff Hoffman for their help in performing these labor-intensive measurements. We also acknowledge the expertise of Wayne Scoggins, John Rodgers, and Rober Martin for electronics and data acquisition support and of Jim Mahan for technical graphics support. We also thank the employees of the Plutonium Facility for tolerating our unannounced measurements. Our appreciation to Lee McAlce, Julio Castro, and Jeff Whicker of Operational Health Physics for coordinating the health and safety aspects of our visit. We thank the staff of the Instrumentation and Calibration Group for their support in using the Neutron Well Calibration Facility. Our appreciation is extended to Drs. Robert Devine and Bill Inkret for their technical review. Last, we thank the many radiological control technicians at the Plutonium Facility who helped provide a pleasant working environment with the specific goal of further understanding and improving the working environment at this impressive facility. 


\section{REFERENCES}

1. Harvey, W. F., J. M. Hoffman, J. L. Bliss and Brake, R. J. Neutron Dosimetry Improvements at Los Alamos National Laboratory. In Press, Radiat. Prot. Dosim. as the "Proceedings of the 10th International Solid State Dosimetry Mecting." Washington D.C. (1992).

2. Bramblett, R. L., Ewing, R. I. and Bonner, T. W. A New Type of Neutron Spectrometer. Nucl. Instrum. Methods 9. 1-12 (1960).

3. Awschalom, M. and R. S. Sanna. Applications of Bonner Sphere Detectors in Neutron Field Dosimetry. Radiat. Prot. Dosim. 10, 89-101 (1985).

4. Cross., W. G. and Ing, H. Neutron Spectroscopy. In: The Dosimetry of lonizing Radiation. Eds., K.R. Kase, B.E. Bjarngard and F.H. Altix, Vol. II (New York: Academic Press) pp. 91-167 (1987).

5. Alevra, A. V., Cosack, M., Hlunt, J. B., Thomas, D. J. and Schraube, H. Experimental Determination of the Response of Four Bonner Sphere Sets to Monoenergetic Neutrons (andreferences contained within). Radiat. Prot. Dosim. 23, 293-296 (1988)

6. Liu, J. C.. Hajnal, F., Sims, C. S. and Kuiper, J. Neutron Spectral Measurements at ORNL. Radiat. Proc. Dosim. 30, 169-178 (1990).

7. Alvera, A. V., Cosack, M., Hunt, J. B., Thomas, D. J. and Schraube H. Experimental Determination of the Response of Four Bonner Sphere Sets to Monoenergetic Neutrons (II) (and references contained within). Radiat. Prot. Dosim. 40, 91-102 (1992).

8. Maerker, R. E., Williams, L. R., Mynatt, R. R. and Greene, N. M. Response Functions for Bonner Ball Neutron Detec. tors (Oak Ridge National Laboratory, Oak Ridge, IN) ORNL-TM-3451 (1971).

9. Burgart, C. E. and Emmett, M. B. Monte Carlo Calculations of the Response Functions of Bonner Ball Neutron Detectors (Oak Ridge National Laboratory, Oak Ridge, 'IN) ORNI.TM-3739 (1972).

10. Dolias, M., Brosson, M., Lefol, C. and Portheos, L. Response of Moderator Spheres to Monoenergetic Neutrons in the Range $5 \mathrm{keV}$ to $6(0) \mathrm{keV}$. Comm. Eur. Communities, EUR-4791 (1972).
11. Hajnal, F. An Iterative Nonlinear Unfolding Code: TWOGO (Environmental Measurements Laboratory New York, NY) EML-391 (1981).

12. Canberra Nuclear Products, Nuclear Data Systems Group, AccuSpec Version-03, Golf and Meacham Roads, Schaumberg, IL (1990).

13. Eberline, a subsidy of Thermo Instrument System, Inc., P.O. Box 2108, Santa Fe, NM.

14. Griffith, R. V., Palfalvi, J., and Madhvanath U. In: Compendium of Neutron Sprctra and Detector Responses for Radiation Protection Purposes. IAEA Technical Reports Series No. 318. International Atomic Energy Agency, Vienna (1990).

15. Olsher, R. H. Calibration Correction Factors for the Los Alamos Neutron Well. Los Alamos National Laboratory Report LA·12127-MS (1991).

16. Bubble Technology Industries Revised Report BTI 90/ 4-14: Response of BD-1OOR With Neutron Energy for a Detector Sensitivity $=1.0(1990)$. BTI Bubble Technology Industries, Hwy. 17, Chalk River, Ontario, Canada.

17. Pachner, J. Handbook of Numerical Analysis Applications: With Programs for Engineers and Scientists. McGraw-Hill, Inc., New York, NY (1984).

18. National Council on Radiation Protection and Measurements (NCRP). Protection Against Neutron Radiation, NCRP Report 38, Washington D.C.: National Council on Radiation Protection and Measurements (1987).

19. U.S. Department of Energy. DOE Order 5480.11: Radiation Protection For Occupational Workers. Assistant Secretary for Environment Safety and Health, Washington D.C. (1988).

20. American National Standards Institute/American Nuclear Society. Neutr, Factors, Document ANSI/ANS 6.1.1-1977 (1977).

21. U.S. Department of Energy. Radiological Control Manual. Drcument DOE/EH-0256T, Assistant Secretary for Environment Safety and IIealth Washington, D.C. (1992). 
22. Intermational Commission on Radiological Protection (ICRP). 1990 Recommendations of the International Commission on Radiological Protection. Publication 60 , Pergamon Press, Oxford (1990).

23. Jorden, T. Computer Code MCNP4/PC (Experimental and Mathematical Physics Consultants, Post Office Box 3191, Gaithersburg, MD, 1991); source code written at Los Alamos National Laboratory; available through Oak Ridge National Laboratory RSIC Computer Code Collection: Monte Carlo Neutron and Photon Transport Code System CCC-200A/B (1991).

24. Matlack, G. M. and Metz, C. F. Radiation Characteristics of Plutonium-238. Los Alamos National Laboratory Report: LA.3696 (1967).

25. Latimer, T. W., Tinehart, G. H., George, T. G., Frantz, C. E., and Land, C. C. Multiwatt Generator Project April 1986. March 1988. Los Alamos National Laboratory Report LA-12236-PR (1992).

26. Keenen, T. K., Kent, R. A., Mulford, R. N. R. and Shupe, M. W. Data Sheets for PPO Radioisotopic Fuel. Los Alamos National Laboratory Report LA-5160-MS, Revision 1 (1974).

27. Peterson, D. E. and Mulford, R. N. R. Analysis of Carbon Monoxide Production in Multihundred-Watt Heat Sources. Los Alamos National Laboratory Report LA-6376-MS (1976).

28. Radcal Corporation, 426 West Duarte Road, Monrovia, CA.

29. Hankins, D. E. The Effect of Energy Dependence on the Evaluation of Albedo Neutron Dosimeters. In Proc. 9th MidYear Topical Symp. of the Health Physics Society, Denver, CO (1975).

30. Hajnal, F., Sanna, R. S., Ryan, R. M., and Donnelly, E. H. Stray Neutron Fields in the Containments of PWRs. In: Occupational Radiation Exposure in Nuclear Fuel Cycle Facilities (Proc. Symp. Neutron Dosimetry, Los Angeles, 1979), IAEA Report IAEA- SM-242/24, Vienna, 397 (1980).

31. Vylet, V., Swaja, R. E., Pretre, S., Valley, V.F. and Lerch, P. On the Use of the "9-10-3" Ratio With Albedo and Fission Track Neutron Personnel Dosimeters. Radiat. Prot. Dosim. 27, 29-33 (1989).
32. Stanford, N., McCurdy, D. E. A Single TLD Dose Algorithm to Satisfy Federal Standards and Typical Field Conditions. Health Phys. 58, 691-704 (1990).

33. Liu, J. C. and Sims, C. S. Performance Evaluation of a New Combination Personnel Neutron Dosimeter. Radiat. Prot. Dosim. 32, 33-43 (1990).

34. Apfel, R. E. and Roy, S. C. Superheated Drop Detector: A Possible Alternative for Neutron Dosimetry. Radiat. Prot. Dosim. 10, 327-330 (1985).

35. Perks, C. A., Devine, R. T., Harrison, K. G., Goodenough, R. J Hunt, J. B., Johnson, T. L., Reil, G. L. and Schwartz, R. B. Neutron Dosimetry Studies Using the New Chalk River Nuclear Laboratories Bubble-Damage Detector. Radiat. Prot. Dosim. 23, 131-134, (1988).

36. Hankins, D. E., Homann, S. G., Buddemeier, B. Personnel Neutron Dosimetry Using Electrochemically Etched CR-39 Foils. Lawrence Livermore National Laboratory Publication UCRL-53833, Revision 1 (1989).

37. American National Standards Institute/American Nuclear Society. Neutron and Gamma-Ray-Fluence-to-Dose Factors, document ANSUANS-6.1.1-1991 (1991).

38. Borland International, Inc. Turbo Basic. 4585 Scott Valley Drive, Scotts Valley, CA (1988).

39. Lotus Development Corporation. Lotus 1-2-3, Version 3.1. 55 Cambridge Parkway, Cambridge, MA (1991). 


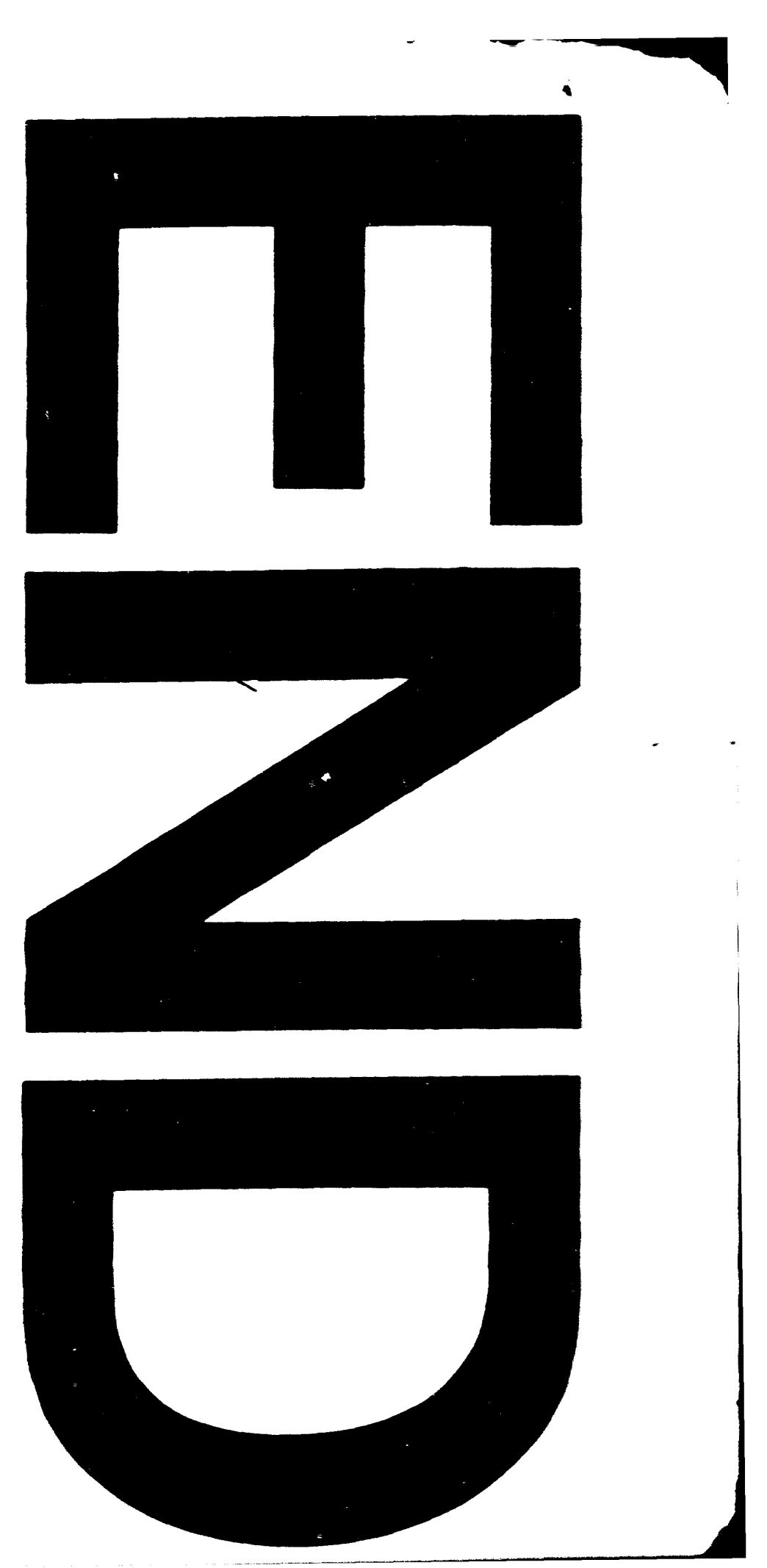


